\title{
Research Status and Challenges of Data-Driven Construction Project Management in the Big Data Context
}

\author{
Yao Huang $\mathbb{D}^{1},{ }^{1}$ Qian Shi $\mathbb{D}^{2},{ }^{2}$ Jian Zuo, ${ }^{3}$ Feniosky Pena-Mora, ${ }^{4}$ and Jindao Chen ${ }^{5}$ \\ ${ }^{1}$ School of Traffic \& Transportation Engineering, Changsha University of Science \& Technology, Changsha 410114, China \\ ${ }^{2}$ Department of Construction Management and Real Estate, Tongji University, Shanghai 200092, China \\ ${ }^{3}$ School of Architecture \& Built Environment, The University of Adelaide, Adelaide 5001, Australia \\ ${ }^{4}$ Department of Civil Engineering and Engineering Mechanics, Columbia University, New York 10027, USA \\ ${ }^{5}$ School of Economics and Statistics, Guangzhou University, Guangzhou 510006, China \\ Correspondence should be addressed to Qian Shi; qianshi@tongji.edu.cn
}

Received 7 October 2020; Revised 3 March 2021; Accepted 25 March 2021; Published 14 April 2021

Academic Editor: Wen Yi

Copyright (C) 2021 Yao Huang et al. This is an open access article distributed under the Creative Commons Attribution License, which permits unrestricted use, distribution, and reproduction in any medium, provided the original work is properly cited.

\begin{abstract}
The construction industry is facing a data tsunami, while emerging information technologies (IT) show great potential for the effective processing of these data or information. However, a comprehensive review for technological change, the resulting process, and organizational changes in the Big Data context, especially from the angle of whole lifecycle of construction project, is lacking. To fill the void, related works published in the databases of Web of Science, Science Direct, and American Society of Civil Engineers library are systematically reviewed. The general trend in emerging IT application in terms of construction project management (CPM) phases, technology and application, and research topics are revealed. Following this analysis, the particularized proposals in relation to each of the main topics within CPM is discussed. Furthermore, according to the advances and limitations of the current literature, corresponding future agendas such as the implementation of comprehensive data-driven $\mathrm{CPM}$ scenario are proposed to bridge the gaps between theoretical research and practical demands.
\end{abstract}

\section{Introduction}

There are two reasons as to why the construction industry is facing a data tsunami. Firstly, the complexity of Construction Project is increasing. This is especially the case for megaprojects that are regarded as data-driven complex systems [1-3]. Secondly, a large number of advanced information technologies (IT) have been introduced to the construction domain. These include: building information modeling (BIM), wireless sensor networks (WSN), Internet of things- (IoTs-) related technologies, etc. [4-6]. With the use of these technologies, a myriad of multisource heterogeneous data are generated. For example, the design data of BIM for a typical three-story building may exceed 50GB in size [7]. Ultimately, these led to the arrival of the Big Data era in the construction domain $[8,9]$. Therefore, it is imperative to explore the potential changes to and possible innovation of construction project management (CPM) within the context of Big Data.
There are a number of definitions for Big Data. One definition of Big Data is the dataset that cannot be collected, managed, and processed with regular software tools for a certain period of time [10]. Another description is the data that exceed the capabilities of the organization to store or analyze for accurate and timely decision-making $[11,12]$. It is well recognized that Big Data share " $4 \mathrm{~V}$ " characteristics, i.e., Volume, Velocity, Variety, and Value $[13,14]$. There are two complementary aspects of Big Data value chain in the process of construction project management (CPM), i.e., Big Data management and (BDM) and Big Data analytics and visualization $(\mathrm{BDA} \& \mathrm{~V})[8,13,15]$. BDM provides an infrastructure to $\mathrm{BDA} \& \mathrm{~V}$, where data management techniques, tools, and platforms, including generation, acquisition, storage, processing, and security can be applied [16].

Comparing to other industries, such as service and manufacturing, the architectural, engineering, construction 
(AEC) industry has unique characteristics [15, 17, 18]. For example, due to large scale and complexity, construction projects not only need to take long time of execution but also involve a large number of stakeholders across the entire lifecycle management (LCM). From project initialization, planning, and implementation to delivery, a huge amount of multisource heterogeneous data are produced [6]. Such datasets are so large and heterogeneous that they present a significant challenge to deal with them efficiently by means of traditional database technologies. The relatively clear fact is that the construction industry still falls behind other industries in terms of Big Data utilization $[9,13]$. Similar to the product lifecycle in the manufacturing industry [15], construction projects' lifecycle also contains several independent phases from planning to decommissioning, namely, planning phase, execution phase, maintenance phase, etc. $[19,20]$. Although each lifecycle phase seems to only produce data related to participants or tasks in this phase, the reality is that mass data would flow into different phases and interact with each other [6]. Therefore, effective CPM requires the realization of adequate information sharing and data-driven decision-making across the whole project lifecycle $[19,21]$, especially for complex megaprojects [5]. As a result, the next innovation wave of CPM uses emerging IT (or Big-Data-related technology) to achieve real-time communication between stakeholders, and utilizes valuable knowledge that is extracted by Big Data analytics to support decision-making $[8,22]$. This revolution in the construction industry gave birth to the concept of digital construction [23].

Digital construction has elicited growing attention. Previous related reviews mainly focused on using Big-Datarelated technology or analytics to serve each of the construction goals and tasks separately (e.g., $[6,8])$. Nevertheless, a systematic review for technological change, the resulting managerial process, and organizational changes in the Big Data context, especially from the angle of the whole lifecycle of construction project, is lacking. This study fills the void and proposes the path to achieve a comprehensive data-driven CPM scenario based on technological, process, and organizational innovations within the context of Big Data. This work is organized as follows: The authors first introduce the background and analyze the differences between previous related reviews and this work as well as illustrate the research method. Next, they review the general trend in Big-Datarelated technology application in terms of CPM phases, technology and application, and focused topics. Following this analysis, they discuss the particularized proposals in relation to each of the main topics within CPM. Finally, they propose future research agendas for the major gaps within the existing body of knowledge to facilitate the data-driven CPM in the Big Data environment.

\section{Related Work}

The IT revolution in the construction industry gave birth to the concept of digital construction [23]. Table 1 shows the related work on literature reviews for digital construction. Related reviews focused on either a certain aspect of construction management or a particular technique application. For example, $[5,24]$ and [25] focused on technologysupported supply chain, organization, and energy management, respectively; [26, 27] primarily focused on a particular technique (e.g. data mining or artificial intelligence) application in the construction domain. Furthermore, two reviews $[6,8]$ focused on the state-of-the-art review of the adoption of IT or Big Data in the construction industry. Nevertheless, [6] did not mention Big Data environment and Big Data analytics but discussed the application prospect of IT in various construction management tasks from the traditional sense. Reference [8] explicitly proposed Big Data in the construction industry, while it mainly focused on using Big Data combined with the specific technology to serve different construction goals and tasks separately.

Unlike previous reviews, our work primarily discusses a comprehensive scenario of data-driven CPM from the angle of whole project lifecycle within the context of Big Data. The comprehensive scenario of data-driven CPM is powered by AI-based Big Data analytics and the state-of-the-art technology-innovations-based collaborative infrastructure. Moreover, the previous reviews mainly focused on the technological change in CPM, whereas our work further explores the changes of managerial process and organizational model based on technological change. For example, our work reveals that data-driven technological innovation lays the foundation for the organizational and process innovation, and these innovations will further improve the management performance of the construction project.

\section{Review Methodology}

The Web of Science (WOS) core collection database contains the most reputable and influential journals, and is therefore recognized as the most authoritative data source for studying publications of most subjects [28]. Although Scopus has a wider range of coverage than WoS, there are significant overlaps between WoS and Scopus [29]. In addition, the Science Direct and American Society of Civil Engineers library have been employed as the data source in the recent bibliometric reviews in the research field of construction management (e.g., $[5,8,24,26])$. Therefore, in order to ensure that the articles are the most representative and the number of samples is manageable, only peer-reviewed journal articles included in the Science Citation Index databases (i.e. WoS, Science Direct, and American Society of Civil Engineers library) were considered in our work. Other types of publications such as book reviews, conference proceeding papers, editorials, and news items were removed from this study. The timeframe was limited from 1999 to 2020 because the technology prototype of Big Data was introduced to the construction industry in 1999 [30].

Furthermore, a search term hypothesis was posed, and a test search was conducted to establish an overview of the topic as the foundation. Initially, a combination of keywords including Big Data (or large data/massive data/data-driven/data mining) and the construction industry (or civil engineering/AEC/construction project and management) was used, but the searched 
TABLE 1: Related work on literature review for digital construction.

\begin{tabular}{|c|c|c|c|c|c|c|}
\hline Paper & $\begin{array}{l}\text { Cutoff } \\
\text { time }\end{array}$ & Search keywords & Data sources & $\begin{array}{c}\text { Total } \\
\text { selected } \\
\text { papers }\end{array}$ & Statistical analysis & Comments \\
\hline$[24]$ & 2015 & $\begin{array}{c}\text { Information/ } \\
\text { communication technology } \\
\text { AND AEC organization }\end{array}$ & $\begin{array}{c}\text { Web of Science (SCI/ } \\
\text { SSCI), ASCE }\end{array}$ & 145 & $\begin{array}{l}\text { Distribution of journals, } \\
\text { years, citation and } \\
\text { influences of the research, } \\
\text { popular keywords, } \\
\text { research methods, and } \\
\text { levels of ICT application }\end{array}$ & $\begin{array}{c}\text { Focus on the current state } \\
\text { and future directions of } \\
\text { ICT-supported AEC } \\
\text { organizations }\end{array}$ \\
\hline [8] & 2016 & Not available & $\begin{array}{c}\text { ASCE, IEEE, ACM, } \\
\text { and Elsevier Science } \\
\text { Direct Library }\end{array}$ & $\begin{array}{c}\text { Not } \\
\text { available }\end{array}$ & Not available & $\begin{array}{l}\text { Focus on the current state } \\
\text { and future directions of } \\
\text { adoption of Big Data in the } \\
\text { construction industry }\end{array}$ \\
\hline [6] & 2016 & Not available & Not available & 87 & Not available & $\begin{array}{l}\text { Focus on the proposals } \\
\text { that use ICT to provide } \\
\text { access to the data of } \\
\text { construction management }\end{array}$ \\
\hline [5] & 2016 & $\begin{array}{l}\text { Mobile Internet/mobile } \\
\text { computer technology AND } \\
\text { construction/engineering } \\
\text { project supply chain }\end{array}$ & $\begin{array}{l}\text { Web of Science (SCI/ } \\
\text { SSCI), ASCE, and } \\
\text { Science Direct library }\end{array}$ & 101 & $\begin{array}{l}\text { Distribution of journals, } \\
\text { years, countries, research } \\
\text { methods, construction } \\
\text { phases, technologies, and } \\
\text { topics }\end{array}$ & $\begin{array}{l}\text { Focus on the current state } \\
\text { and future directions of } \\
\text { adoption of mobile- } \\
\text { Internet in construction } \\
\text { supply chain management }\end{array}$ \\
\hline [25] & 2018 & Not available & Not available & $\begin{array}{c}\text { Not } \\
\text { available }\end{array}$ & Not available & $\begin{array}{l}\text { Focus on the current state } \\
\text { and future direction of } \\
\text { utilization of unsupervised } \\
\text { data analytics in mining } \\
\text { massive building } \\
\text { operational data }\end{array}$ \\
\hline [26] & 2020 & $\begin{array}{l}\text { Data mining/knowledge } \\
\text { discovery/machine learning/ } \\
\text { big data/text mining/deep } \\
\text { learning AND construction } \\
\text { industry/building } \\
\text { environment }\end{array}$ & $\begin{array}{l}\text { Web of Science, } \\
\text { Science Direct, ASCE, } \\
\text { Engineering Village, } \\
\text { and Taylor \& Francis } \\
\text { Online Library }\end{array}$ & 119 & $\begin{array}{l}\text { Distribution of journals, } \\
\text { years, geographical data } \\
\text { sources, data mining } \\
\text { techniques, and tools }\end{array}$ & $\begin{array}{l}\text { Focus on the current state } \\
\text { and future direction of the } \\
\text { application of data mining } \\
\text { in the construction } \\
\text { industry }\end{array}$ \\
\hline [27] & 2020 & $\begin{array}{c}\text { Artificial intelligence/ } \\
\text { machine learning/neural } \\
\text { networks/data } \\
\text { mining. . .AND construction } \\
\text { industry/civil engineering/ } \\
\text { AEC/construction } \\
\text { engineering and } \\
\text { management... }\end{array}$ & Scopus & 41827 & $\begin{array}{l}\text { Distribution of research } \\
\text { interests, journals, } \\
\text { institutions, and countries }\end{array}$ & $\begin{array}{c}\text { Focus on a state-of-the-art } \\
\text { review of artificial } \\
\text { intelligence in the AEC } \\
\text { industry }\end{array}$ \\
\hline
\end{tabular}

Note. ASCE: American Association of Civil Engineers; IEEE: Institute of Electrical and Electronics Engineers; ACM: Association of Computing Machinery.

literature was relatively limited through those search key phrases. Strategic planning for Big Data applications in the construction domain remains a largely unknown field possibly due to the infancy stage of the technology. Big-Data-related technology is conceptually related to the key information and communication technologies underlying digital construction $[8,23]$. Therefore, the existing emerging information/digital technologies were taken as references similar to most of the related work $[6,8,24,27,31]$.

Emerging information technologies encompass a board spectrum of computing technologies that can be used to create, store, exchange, and use information in various forms, such as hardware, software, telecommunications, intranet and extranet, wireless connection, and social media [24, 32, 33]. This broad definition also led to various search results from the next round. However, many articles mentioned emerging information technologies, but these papers may not refer to specific construction management process explicitly or implicitly. On the contrary, they focused on other topics, such as pure technical system development or mathematical algorithms. To refine the search, this scope was narrowed to articles related only to applying AEC management, such as improving organizational information processing capacity or facilitating project goal management. After automatic and manual screening, 96 articles were identified as the review range of this study. The analyzed proposals (see Table 2) were summarized for each reference: the main phase of the construction project, the research topic focused on, the main technology/technique used, and the data handling link were mostly involved. 
TABLE 2: A summary of the collected references.

\begin{tabular}{|c|c|c|c|c|c|}
\hline No. & Papers & Phases & Research topics & $\begin{array}{l}\text { Technologies } \\
\text { involved }\end{array}$ & $\mathrm{BDM} / \mathrm{BDA} \& \mathrm{~V}$ \\
\hline 1 & {$[34]$} & Construction & Safety management & BIM, GIS & Visualization \\
\hline 2 & [35] & Construction & Safety management & $\mathrm{DM}$ & Analytics \\
\hline 3 & {$[36]$} & Construction & Safety management & $\mathrm{DM}$ & Analytics \\
\hline 4 & [37] & Construction & Safety management & RFID/WBN & Collection/analytics \\
\hline 5 & [38] & Construction & Compliance checking/safety management & RFID & Collection/analytics \\
\hline 6 & [39] & Construction & Safety management & $\mathrm{DM}$ & Analytics \\
\hline 7 & {$[40]$} & Construction & Safety management & $\mathrm{DM}$ & Analytics \\
\hline 8 & {$[41]$} & Construction & Knowledge management & $\mathrm{BIM} / \mathrm{O} / \mathrm{SA}$ & Analytics/visualization \\
\hline 9 & {$[42]$} & Construction & $\begin{array}{l}\text { Safety management } / \text { real-time information } \\
\text { communication }\end{array}$ & $\mathrm{RFID} / \mathrm{ML} / \mathrm{CV}$ & $\begin{array}{c}\text { Collection/analysis/ } \\
\text { visualization }\end{array}$ \\
\hline 10 & {$[43]$} & Construction & Safety management & $\mathrm{ML} / \mathrm{CV}$ & Collection/analysis \\
\hline 11 & {$[44]$} & Construction & Safety management & $\mathrm{ML} / \mathrm{CV}$ & Analysis/visualization \\
\hline 12 & {$[45]$} & Construction & Safety management & $\mathrm{ML} / \mathrm{CV}$ & Analysis/visualization \\
\hline 13 & {$[46]$} & $\mathrm{Bid} /$ procurement & Bid management/cost control & $\mathrm{DM} / \mathrm{ML}$ & Analytics \\
\hline 14 & [47] & $\mathrm{Bid} /$ procurement & Cost control & $\mathrm{BIM} / \mathrm{O} / \mathrm{SA}$ & Analytics \\
\hline 15 & {$[48]$} & $\mathrm{Bid} /$ procurement & Cost control & $\mathrm{BIM} / \mathrm{O} / \mathrm{SA}$ & Analytics \\
\hline 16 & [49] & Bid/procurement & Progress monitoring/supply chain management & RFID/BIM & $\begin{array}{l}\text { Collection/ } \\
\text { visualization }\end{array}$ \\
\hline 17 & {$[50]$} & Construction & Progress monitoring & LS/AR & $\begin{array}{l}\text { Collection/ } \\
\text { visualization }\end{array}$ \\
\hline 18 & {$[51]$} & Construction & Progress monitoring & BIM & Visualization \\
\hline 19 & {$[52]$} & Construction & Progress monitoring & LS & Collection/integration \\
\hline 20 & {$[53]$} & Construction & Resources arrangement & $\begin{array}{l}\mathrm{KDD} / \mathrm{OLAP} / \mathrm{DM} / \\
\mathrm{DW}\end{array}$ & Analytics \\
\hline 21 & {$[54]$} & Construction & Progress monitoring & BIM & Analytics/visualization \\
\hline 22 & {$[55]$} & $\mathrm{Bid} /$ procurement & Cost control & $\mathrm{KDD} / \mathrm{DM}$ & Analytics \\
\hline 23 & {$[56]$} & $\begin{array}{l}\text { Operation/ } \\
\text { maintenance, } \\
\text { construction }\end{array}$ & Quality inspection & ML & Analytics \\
\hline 24 & {$[57]$} & $\begin{array}{l}\text { Operation/ } \\
\text { maintenance, } \\
\text { construction }\end{array}$ & Quality inspection & ML & Analytics \\
\hline 25 & {$[58]$} & Bid/procurement & Supply chain management & RFID/PDA & $\begin{array}{l}\text { Integration/analytics/ } \\
\text { visualization }\end{array}$ \\
\hline 26 & {$[59]$} & $\begin{array}{c}\text { Planning/deign, bid/ } \\
\text { procurement }\end{array}$ & supply chain management & RFID & collection/analytics \\
\hline 27 & {$[60]$} & Operation/maintenance & Quality inspection & $\mathrm{PAD} / \mathrm{WB}$ & $\begin{array}{l}\text { Integration/ } \\
\text { visualization }\end{array}$ \\
\hline 28 & {$[61]$} & Operation/maintenance & Quality inspection & DC & $\begin{array}{l}\text { Collection/analytics/ } \\
\text { visualization }\end{array}$ \\
\hline 29 & {$[62]$} & $\begin{array}{l}\text { Construction, } \\
\text { operation/maintenance }\end{array}$ & Quality inspection & $\mathrm{ML} / \mathrm{DM}$ & Analytics \\
\hline 30 & {$[63]$} & Operation/maintenance & Quality inspection & ML & Processing/analytics \\
\hline 31 & {$[64]$} & Operation/maintenance & Quality inspection/emergency response & BIM & Analytics/visualization \\
\hline 32 & {$[65]$} & Operation/maintenance & Quality inspection & $\mathrm{DM} / \mathrm{ML}:$ & Analytics \\
\hline 33 & {$[66]$} & Operation/maintenance & Quality inspection & $\mathrm{ML} / \mathrm{WBN}$ & Integration \\
\hline 34 & {$[67]$} & Operation/maintenance & Building energy management & $\mathrm{DM} / \mathrm{BMS} / \mathrm{KDD}$ & Analytics/visualization \\
\hline 35 & {$[68]$} & Operation/maintenance & Building energy management & $\begin{array}{l}\mathrm{DM} / \mathrm{BMS} / \mathrm{KDD} / \\
\mathrm{BAS}\end{array}$ & Analytics/visualization \\
\hline 36 & [69] & $\begin{array}{l}\text { Planning/deign, } \\
\text { operation/maintenance }\end{array}$ & Building energy management & $\mathrm{BIM} / \mathrm{BMS}$ & $\begin{array}{c}\text { Collection/ } \\
\text { visualization }\end{array}$ \\
\hline 37 & {$[70]$} & Operation/maintenance & Building energy management & $\mathrm{BIM} / \mathrm{BMS}$ & $\begin{array}{l}\text { Collection/storage/ } \\
\text { visualization }\end{array}$ \\
\hline 38 & {$[25]$} & Operation/maintenance & Building energy management & $\mathrm{DM}$ & Analytics \\
\hline 39 & {$[71]$} & Bid/procurement & Bidding management & KDD & Analytics \\
\hline 40 & {$[72]$} & Bid/procurement & Bidding management/knowledge management & $\begin{array}{l}\mathrm{CC} / \mathrm{SOA} / \mathrm{BIM} / \\
\mathrm{WB} / \mathrm{VR}\end{array}$ & Collection/processing \\
\hline 41 & [73] & $\begin{array}{l}\text { Bid/procurement, } \\
\text { construction }\end{array}$ & Supply chain management & WBN & Collection/processing \\
\hline
\end{tabular}


TABle 2: Continued.

\begin{tabular}{|c|c|c|c|c|c|}
\hline No. & Papers & Phases & Research topics & $\begin{array}{l}\text { Technologies } \\
\text { involved }\end{array}$ & $\mathrm{BDM} / \mathrm{BDA} \& \mathrm{~V}$ \\
\hline 42 & {$[74]$} & $\begin{array}{l}\text { Bid/procurement, } \\
\text { construction }\end{array}$ & Supply chain management & RFID & Collection/processing \\
\hline 43 & {$[75]$} & $\begin{array}{l}\text { Bid/procurement, } \\
\text { construction }\end{array}$ & Supply chain management & RFID & Collection/integration \\
\hline 44 & {$[76]$} & Construction & Supply chain management & RFID & Collection/processing \\
\hline 45 & {$[77]$} & Construction & Resources arrangement & $\mathrm{KDD} / \mathrm{DM}$ & Collection/integration \\
\hline 46 & {$[78]$} & $\begin{array}{c}\text { Construction, } \\
\text { demolition/recycling }\end{array}$ & Resources arrangement & WB/EIS & $\begin{array}{l}\text { Collection/storage/ } \\
\text { analytics }\end{array}$ \\
\hline 47 & {$[79]$} & $\begin{array}{c}\text { Planning/design, } \\
\text { demolition/recycling }\end{array}$ & Wastes management & BIM & Storage/analytics \\
\hline 48 & {$[80]$} & $\begin{array}{l}\text { Planning/design, } \\
\text { construction }\end{array}$ & Real-time information communication & $\begin{array}{l}\text { VR/PDA/GIS/ } \\
\text { WBN }\end{array}$ & Visualization \\
\hline 49 & {$[31]$} & Construction & Real-time information communication & WBN/SA/WB/AB & $\begin{array}{l}\text { Integration/ } \\
\text { transformation }\end{array}$ \\
\hline 50 & {$[81]$} & Construction & $\begin{array}{l}\text { Real-time information communication/ } \\
\text { organization, integration, and collaborative }\end{array}$ & WBN & Transformation \\
\hline 51 & {$[82]$} & Construction & $\begin{array}{c}\text { quality inspection/real-time information } \\
\text { communication/organization, integration, and } \\
\text { collaborative }\end{array}$ & $\mathrm{DC} / \mathrm{WB} / \mathrm{WBN}$ & $\begin{array}{l}\text { Collection/integration/ } \\
\text { storage/visualization }\end{array}$ \\
\hline 52 & {$[83]$} & Construction & $\begin{array}{l}\text { Real-time information communication/ } \\
\text { organization, integration, and collaborative }\end{array}$ & $\begin{array}{l}\text { RFID/WBN/PDA/ } \\
\text { DC }\end{array}$ & $\begin{array}{l}\text { Collection/ } \\
\text { transformation }\end{array}$ \\
\hline 53 & {$[84]$} & $\begin{array}{l}\text { Planning/design, } \\
\text { construction }\end{array}$ & $\begin{array}{l}\text { Real-time information communication/ } \\
\text { information integration }\end{array}$ & BIM/AR/RFID/LS & $\begin{array}{l}\text { Integration/ } \\
\text { visualization }\end{array}$ \\
\hline 54 & {$[5]$} & Bid/procurement & $\begin{array}{l}\text { Supply chain management/real-time information } \\
\text { communication/organization, integration, and } \\
\text { collaborative/relationship management }\end{array}$ & $\begin{array}{l}\text { RFID/WB/WBN/ } \\
\text { GPS/SOA/CC }\end{array}$ & $\begin{array}{l}\text { Collection/integration/ } \\
\text { transformation }\end{array}$ \\
\hline 55 & {$[85]$} & Whole lifecycle & Information integration/relationship management & CC/SNA/BIM & $\begin{array}{l}\text { Integration/storage/ } \\
\text { visualization }\end{array}$ \\
\hline 56 & {$[86]$} & Construction & Knowledge management & KDD & Storage/analytics \\
\hline 57 & {$[87]$} & Construction & Organization, integration, and collaborative & PDA & Visualization \\
\hline 58 & {$[88]$} & Construction & Organization, integration, and collaborative & WB & $\begin{array}{l}\text { Integration/ } \\
\text { transformation }\end{array}$ \\
\hline 59 & [89] & Construction & Organization, integration, and collaborative & $\mathrm{WBN} / \mathrm{WB} / \mathrm{AB} / \mathrm{VR}$ & $\begin{array}{l}\text { Integration/ } \\
\text { transformation }\end{array}$ \\
\hline 60 & {$[90]$} & $\begin{array}{l}\text { Planning/design, bid/ } \\
\text { procurement, } \\
\text { construction }\end{array}$ & Organization, integration, and collaborative & $\mathrm{CC} / \mathrm{AB} / \mathrm{WB}$ & Processing/storage \\
\hline 61 & {$[91]$} & $\begin{array}{l}\text { Planning/design, bid/ } \\
\text { procurement, } \\
\text { construction }\end{array}$ & $\begin{array}{c}\text { Supply chain management/relationship } \\
\text { management }\end{array}$ & $\mathrm{AB} / \mathrm{WB}$ & $\begin{array}{l}\text { Integration/ } \\
\text { transformation }\end{array}$ \\
\hline 62 & {$[92]$} & $\begin{array}{l}\text { Planning/design, bid/ } \\
\text { procurement, } \\
\text { construction }\end{array}$ & $\begin{array}{c}\text { Supply chain management/relationship } \\
\text { management }\end{array}$ & $\begin{array}{l}\text { SOA/RFID/WBN/ } \\
\text { WB }\end{array}$ & Integration \\
\hline 63 & {$[93]$} & Whole lifecycle & Asset ma & BIM/GIS & Storage/visualization \\
\hline 64 & {$[94]$} & Operation/maintenance & Asset management & BIM & Integration/storage \\
\hline 65 & [95] & Construction & Asset management & $\mathrm{AR}$ & Visualization \\
\hline 66 & {$[96]$} & Construction & Crowdsourcing & $\mathrm{CC} / \mathrm{DC} / \mathrm{ML}$ & $\begin{array}{l}\text { Collection/analytics/ } \\
\text { visualization }\end{array}$ \\
\hline 67 & {$[97]$} & Construction & Crowdsourcing & $\begin{array}{l}\mathrm{CV} / \mathrm{ML} / \mathrm{DC} / \mathrm{BIM} / \\
\mathrm{AR}\end{array}$ & $\begin{array}{l}\text { Collection/analytics/ } \\
\text { visualization }\end{array}$ \\
\hline 68 & {$[98]$} & Construction & $\begin{array}{c}\text { Crowdsourcing/progress monitoring/quality } \\
\text { inspection }\end{array}$ & DC/BIM & $\begin{array}{l}\text { Collection/analytics/ } \\
\text { visualization }\end{array}$ \\
\hline 69 & [99] & $\begin{array}{l}\text { Bid/procurement, } \\
\text { construction }\end{array}$ & Electronic commerce model & WB & Integration \\
\hline 70 & {$[100]$} & $\begin{array}{l}\mathrm{Bid} / \text { procurement, } \\
\text { construction }\end{array}$ & Electronic commerce model & $\mathrm{WB} / \mathrm{WNB}$ & Integration \\
\hline 71 & {$[101]$} & planning/design & Design $s$ & $\mathrm{DM}$ & Analytics/visualization \\
\hline 72 & {$[102]$} & Planning/design & Design support & BIM & Analytics/visualization \\
\hline
\end{tabular}


TABLE 2: Continued.

\begin{tabular}{|c|c|c|c|c|c|}
\hline No. & Papers & Phases & Research topics & $\begin{array}{l}\text { Technologies } \\
\text { involved }\end{array}$ & $\mathrm{BDM} / \mathrm{BDA} \& \mathrm{~V}$ \\
\hline 73 & {$[103]$} & Construction & Compliance checking & SA/NLP & $\begin{array}{c}\text { Processing/storage/ } \\
\text { analytics }\end{array}$ \\
\hline 74 & {$[104]$} & Construction & Compliance checking/safety management & AR/GIS/NLP & $\begin{array}{l}\text { Processing/storage/ } \\
\text { analytics/visualization }\end{array}$ \\
\hline 75 & {$[105]$} & Construction & Compliance checking & SA/NLP/ML & Storage/analytics \\
\hline 76 & {$[106]$} & Construction & Claim management & ML & Analytics \\
\hline 77 & {$[107]$} & Construction & Claim management & $\mathrm{ML} / \mathrm{CBR}$ & Analytics \\
\hline 78 & {$[108]$} & Operation/maintenance & Emergency response & GIS/RFID/WBN & $\begin{array}{c}\text { Collection/analytics/ } \\
\text { visualization }\end{array}$ \\
\hline 79 & [109] & Operation/maintenance & Emergency response & RFID & Collection/analytics \\
\hline 80 & {$[110]$} & Construction & Emergency response & AR & Storage/visualization \\
\hline 81 & {$[111]$} & Operation/maintenance & Emergency response & ML & Analytics \\
\hline 82 & {$[112]$} & Operation/maintenance & Emergency response & WBN & Collection/analytics \\
\hline 83 & {$[113]$} & Operation/maintenance & Quality inspection/knowledge management & $\mathrm{BIM} / \mathrm{CBR}$ & $\begin{array}{l}\text { Storage/analytics/ } \\
\text { visualization }\end{array}$ \\
\hline 84 & {$[114]$} & Whole lifecycle & Information integration/knowledge management & $\mathrm{BIM} / \mathrm{CC} / \mathrm{NLP}$ & $\begin{array}{l}\text { Generation/collection/ } \\
\text { integration/storage }\end{array}$ \\
\hline 85 & {$[115]$} & on & Resc & $\mathrm{WBN} / \mathrm{ML} / \mathrm{CC}$ & Collection/analytics \\
\hline 86 & {$[116]$} & Construction & Resources arrangement & GPS & Collection/analytics \\
\hline 87 & {$[117]$} & Construction & Progress monitoring & GIS & Analytics/visualization \\
\hline 88 & {$[118]$} & Construction & Progress monitoring & KDD & Analytics \\
\hline 89 & {$[119]$} & $\mathrm{Bid} /$ procurement & Knowledge management & NLP & Analytics \\
\hline 90 & {$[120]$} & Operation/maintenance & Quality inspection & ML & Analytics \\
\hline 91 & {$[121]$} & Construction & Knowledge management & $\mathrm{ML} / \mathrm{SA}$ & Analytics \\
\hline 92 & {$[122]$} & Construction & Safety management & WBN & Collection/processing \\
\hline 93 & {$[123]$} & Construction & Safety management & WBN & Collection/processing \\
\hline 94 & {$[124]$} & Construction & Knowledge management/resource arrangement & $\mathrm{DM} / \mathrm{WB}$ & Analytics \\
\hline 95 & [125] & Bid/procurement & Knowledge management & RFID & Collection/storage \\
\hline 96 & [126] & Whole lifecycle & $\begin{array}{l}\text { Real-time information communication/supply } \\
\text { chain management }\end{array}$ & BIM & $\begin{array}{c}\text { Collection/ } \\
\text { visualization }\end{array}$ \\
\hline
\end{tabular}

Note: WBN, wireless-based network; O, ontology; SA, semantic analysis; CV, computer vision; LS, laser scanning; DW, data warehouse; WB, web-based; DC, digital camera; $\mathrm{CC}$, cloud computing; $\mathrm{AB}$, agent-based.

\section{Descriptive Analysis}

4.1. Different Phases of CPM. The whole lifecycle of construction projects consists of various phases from planning, design, bid/procurement, construction, operation/maintenance to final demolition and recycling $[19,20]$. As shown in Figure 1, it is worth noting that just a few articles involve the whole lifecycle of construction projects. Compared to product LCM, which integrates each phase from planning to demolition or recycling, construction project management is traditionally divided into separate phases [127]. The traditional project management model was mainly based on the reductionism. Thus, some innovative project management approaches (e.g. the meta-synthesis pattern of project management) have been put forward in a bid to improve the project management performance [128, 129]. Nowadays, the emergence of Big-Data-related technologies in the construction domain is more conductive to metasynthesis of LCM. Nearly 60 out of 96 articles focus on the construction phase, which indicates that the research of Big Data on the construction phase has received great attention. Significant challenges exist in organizational coordination and objective control, which demands advanced digital tools in this phase $[4,130]$. The number of articles engaged in operation/maintenance or bid/ procurement phases is ranked second and third, respectively. Although it is well recognized that the design phase plays a crucial role in improving the project management performance in construction projects [131], relatively less researches concentrated on this phase so far. It is striking to note that the least research has been done on the demolition/recycling phase. In a word, this suggests that various digital tools or methods used in other phases are far less than those in the construction phase.

4.2. Technology and Application. Because of unstructured traits and the changing environment, the construction industry is often slow in introducing advanced technologies compared to other industries. However, with the development of diversified, advanced technologies, a growing number of practitioners and researchers are aware that the application of state-of-the-art technologies can help to improve the efficiency and effectiveness of CPM. A series of IT related to Big Data have been introduced into the field of CPM by both researchers and 


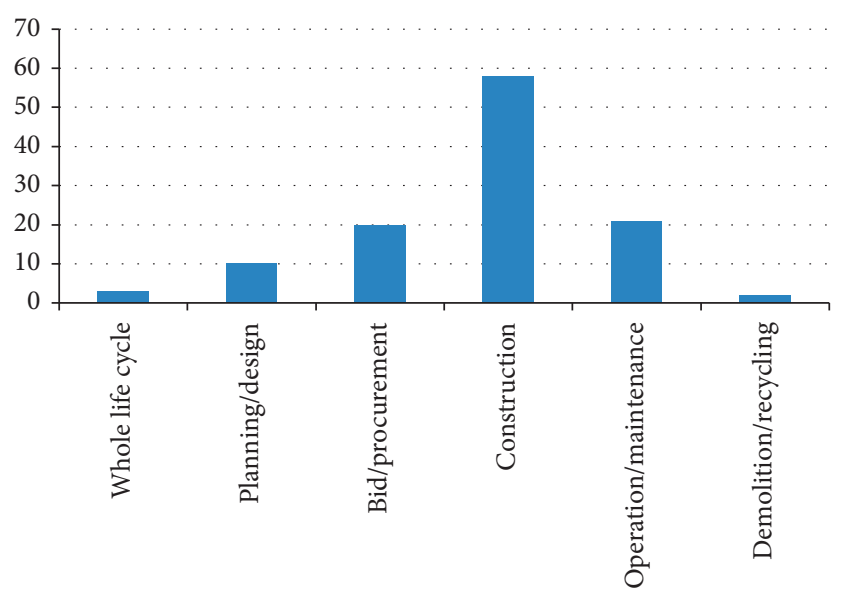

FIGURE 1: Distribution of reviewed articles by project phases.

practitioners. The drivers are to enhance the efficiency of construction production, and to acquire a better understanding of business models. The total use frequency of each technology/technique is illustrated in Figure 2. The occurrence of BIM and ML are most common in CPM. Wireless-based network is widely applied as well, and The use frequency of wireless-based network (WBN) is ranked third. The use frequency of RFID and DM is ranked fourth. According to the application classification, IT related to Big Data reported by previous researches are mainly from the two aspects of BDM and $B D A \& V$. It also reflects the fact that most technology application concentrated on the data analytics and visualization aspects for engineering context (as shown in Figure 3).

4.3. Research Topics. The subjects of the existing studies have been categorized by a range of studies. Most of the articles can be classified into several groups despite the diverse research topics (see Figure 4). Some articles covered more than one research topic, which were calculated separately. As shown in Figure 4, the first group, namely, construction performance management involves safety management, progress monitoring, cost control, quality inspection, and building energy management. The second group addresses bidding management, supply chain management, resources management, and wastes management from the perspective of construction supply chain management and resources optimization. The sum of these two groups is nearly $60 \%$ of total research topics. The research topics also cover technology innovation (i.e., real-time information communication, information integration, and knowledge management), organization innovation (i.e., organization integration and collaborative and relationship management), and process innovation (i.e., asset management, crowdsourcing, and electronic commerce model). In addition, parts of articles paid attention to the other fields such as design support, compliance checking, claim management, emergency response, etc.

\section{Discussion}

Following the statistics and analysis of the existing studies, the particularized proposals in relation to each of the main topics within CPM is discussed.

5.1. Data-Driven Management in Various Phases of Construction. Compared to whole lifecycle of industrial products, which integrates each phase from planning to demolition or recycling, construction project is traditionally divided into separate phases [127]. Specifically, the lifecycle of construction projects consists of various phases from planning/design, bid/procurement, construction, operation/ maintenance to final demolition and recycling $[19,20]$. According to the existing studies, the proposals that apply emerging IT to deal with CPM issues are as follows:

5.1.1. Planning/Design Phase. In the schematic design phase, via the Big-Data-based ontologies inference process and semantic reasoning rule, the process of searching the corresponding work items can be automated, which assists to overcome the subjective bias introduced by the cost estimator during the design budgetary estimating process [47]. Similarly, the data mining technique provides an effective method for engineering design, e.g., through valuable knowledge extracted from a large amount of heterogeneous data to improve their accessibility for engineering designers [101].

5.1.2. Bid/Procurement Phase. A number of Big-Data-related technologies have the potential to be employed in bid/procurement activities. These include the exploration and exploitation of tender evaluation decision support system (DSS) based on KDD [71]. Similarly, VR, Web2.0, and cloud computing technologies were employed to make sure what to be purchased, and how to elaborate the build procurement strategy [72]. In addition, some ML methods (e.g. SVM, decision trees, GA, and ANN) have been used to predict the deviations of duration and cost during the construction bid process [46].

Big-Data-related technologies could enhance the performance of construction supply chain management. The emerging mobile Internet has offered an opportunity to fulfill various participants' demands about sharing the realtime information [5]. A few researches focused on the issue of construction materials tracking. RFID-based materials tracking system can contribute to the efficiency of acquisition and delivery of data involved in material usage as well as storage [74]. Combining with the wireless sensors, relevant experiments had been conducted on construction sites $[73,75,125]$. Some methods were put forward to implement the collection, storage, and retrieval of valid data involved in equipment or materials across LCM of construction projects, for example, RFID-based quality management [59], unified architecture component and parts construction [58], and logistics management or vertical transportation [49]. 


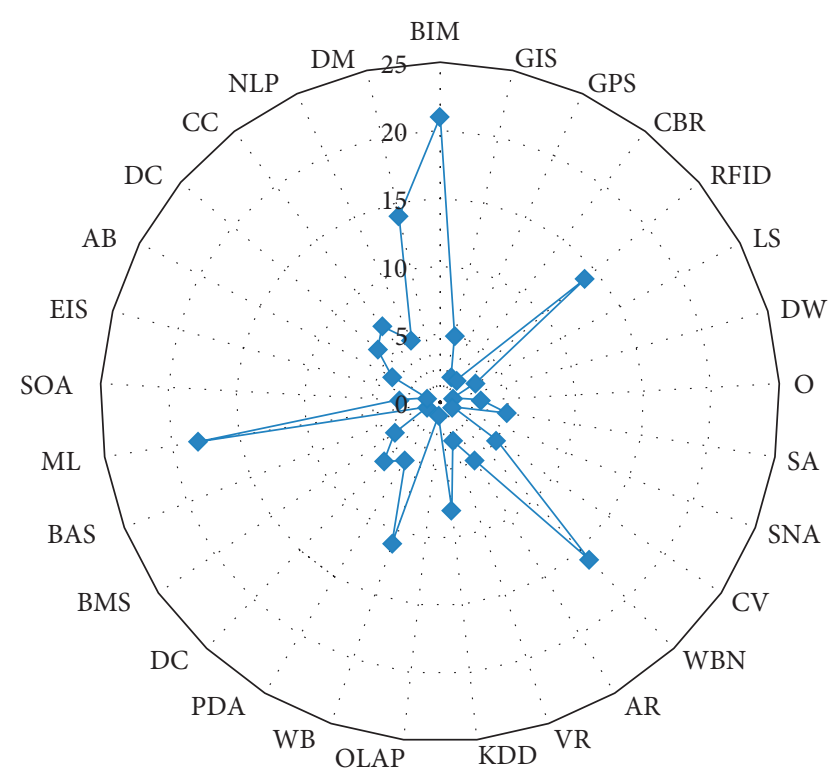

FIgURe 2: Total use frequency of each technology.

5.1.3. Construction Phase. Most of the studies mainly addressed the application of Big Data in the stage of project implementation. Occupational safety and health management present one of the most critical issues in this stage. Association rule-based data mining approach can be utilized to explore cause-effect relationships of safety accidents in the construction domain $[35,36,39,40]$. Integrated advanced technologies (e.g., mobile Internet, WSN, and real-time data transmission) could be used to monitor the safety of crane groups $[122,123]$. RFID portal and tags have been used to check the safety protection equipment of workers [38]. As a real-time location and tracking technology (ZigBee network or WSN), or computer vision technique (CNN-based), can continually check the location of workers and achieve proactive accident prevention on complex construction sites $[37,42,43,45]$. These form an integral part of integral strategies for precaution and accident prevention.

The second main stream of data-driven management research in this phase is the quality inspection. A large amount of quality inspection data collected from construction components or structures can be processed by a machine-learning-based algorithm [63]. ANN-based performance prediction models have gained a broad range of applications in the construction domain. In particular, these models are instrumental for the fault detection of engineering structures, which assists engineers to take appropriate decisions when constructing and rehabilitating the construction structures $[56,57]$. Another main topic of performance management in the construction domain is schedule management. Through image-based reconstruction technique, as-built building information model can be obtained from scanned point cloud models. An integrated BIM-based AR system could determine whether the construction is taking place in accordance with the planned schedule [50, 54, 132].
It is well recognized that improper management of resources (e.g. labor resources, materials, equipment) are the main reasons for schedule delay and budget overrun in construction projects. Therefore, relevant studies on labor resources arrangement attempted to introduce KDD techniques to discover valuable knowledge from large sets of labor resources data, thereby optimizing resource arrangement practices [53]. Meanwhile, knowledge-based simulation was employed to enhance the reliability of queuing systems during the course of construction projects [124]. Construction fleet operations of megaprojects construction are particularly complicated. In order to solve this problem, a knowledge-based simulation modeling has been provided by Akhavian and Behzadan [77] to visualize the process of construction fleet operations throughout multimodal-process data mining.

New approaches to monitor on-site activities during the construction process have been proposed in previous studies. These include the integration of visualized big data with BIM, and using time-lapse photos or video streams [96-98]. In order to achieve automated compliance checking, natural language processing can be used to automatically extract the concepts as well as their relationships from the text of regulations and contracts [103, 104]. Similarly, it has been reported that great potential exists to further apply Big-Data-related technologies to manage claims and contracts. For instance, ML-based approaches have been employed for modeling the judicial reasoning and forecasting the litigation results [106, 107].

5.1.4. Operation/Maintenance Phase. There are two main topics, i.e., quality inspection and energy management, respectively. Quality inspection is one of the most important control objectives in both construction phase and maintenance phase. ML-based algorithm can be employed to assist engineers to make proper decisions while maintaining the construction structures. For instance, Cheng et al. [62] demonstrated that GA-based multilevel association rule mining is an effective method to analyze the defects of buildings. Similarly, a system integrated with a PDA and wireless web could collect real-time defect data to achieve the rapid detection of apartment housing projects [60]. Natural disasters often cause significant damage to construction. A robotic platform was demonstrated efficiently to identify defects in post-disaster construction by means of imagebased automated 3D crack detection [61, 64]. Nowadays, building energy consumption monitoring has become an important topic. Because the real-time building energy monitoring data grow continually, powerful Big Data analysis tools are needed. For example, a time series temporal knowledge discovery in big BAS (building automation systems) data was successfully used by Cabrera et al. [68] for building energy management. Meanwhile, with the growing concern about the whole process management of building energy performance, the reduction of building energy consumption should rely on both effective design and efficient operation. Therefore, previous studies have applied 


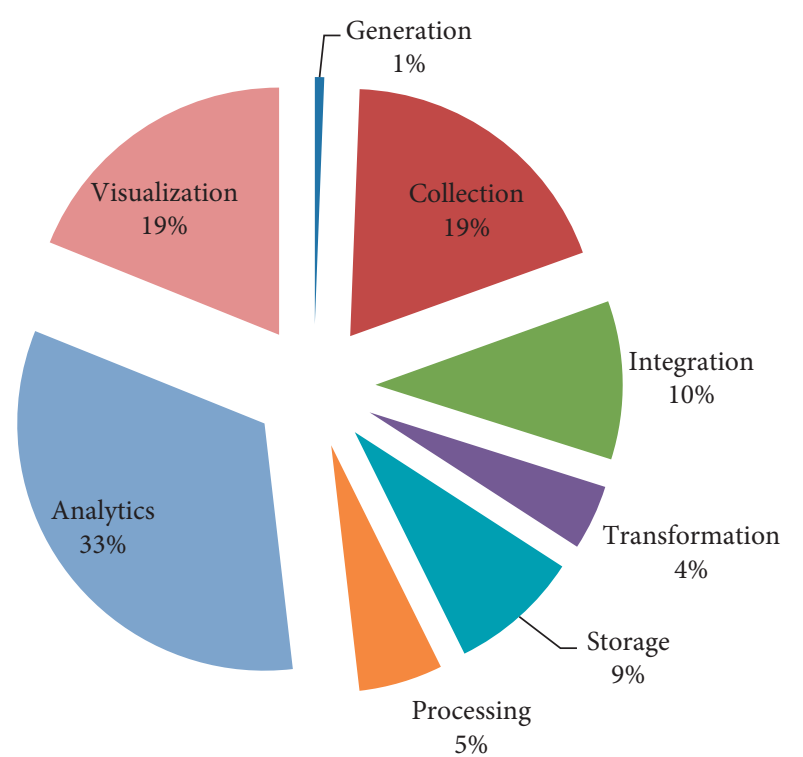

Figure 3: Distribution of reviewed articles by technology application.

BIM together with BMS to support the visualization and improve the building energy performance [69, 70].

Another topic during this phase was emergency response. In order to facilitate disaster response operations, Peña-Mora et al. [108] developed an information-technology-based collaboration framework. Firstly, building-assessment-related information is stored in RFID tags, and then connected with the terminal network through digital devices. When necessary, web-based meetings can be held to evaluate the disaster event. During the firefighting process, AR-based context-aware access assists in acquiring the precise position $[109,110]$. In addition, the premovement time can be shortened through an interactive system, which consists of ZigBee-based localization module and individual wearable devices in case of fire events [112].

5.1.5. Recycling/Demolition Phase. With the rapid development of urbanization, the adverse impact of the bulk of construction wastes on environment has serious implications worldwide. As a result, a desire to proactively tackle construction wastes at the source of design is also getting stronger. Bilal et al. [79] proposed a Big Data architecture for construction waste analytics, which provides a potential possibility for design exploration and optimization to minimize construction waste. In addition, for waste reduction and environmental protection, EIS (Earth information system) was proposed to facilitate the sharing and reusing of surplus resources or the recycling of each construction site [78].

5.2. Data-Driven Innovation of CPM. In addition, as shown in Figure 4, three groups about the technology innovation (i.e. real-time information communication, information integration, and knowledge management), organization innovation (i.e., organization integration and collaborative and relationship management), and process innovation (i.e. asset information delivery, crowdsourcing, and electronic commerce model) were studied, respectively.

5.2.1. Data-Driven Technological Innovation. The technological innovation has presented significant opportunities to the construction industry. Big-data-related technologies can capture multisource data and promote the real-time sharing of information across different participants in construction site [31]. The emergence of ICT and mobile Internet technologies (such as RFID, ad hoc network, wireless network, 3D laser scanning, PDA, and so on) facilitates the information communication and fusion on complex construction site $[81,83]$ and improves the management performance.

Moreover, combining with VR technology, these technologies make it possible for the visualized $3 \mathrm{D}$ models of construction scene to be presented on PDA [80]. AR technology is recognized as a new generation of VR. It can be used for visualizing and monitoring construction activities in CPM. For instance, Wang et al. [84] combined AR technology with BIM to make the on-site situation or construction operations visualized in real-time. Besides, novel sensing and tracking technologies are often operated in conjunction with AR [84].

The advent of Big-Data-related technologies is shifting the management paradigm of many industries, e.g., progressive realization of knowledge management in CPM $[41,72]$, and the introduction of these novel technologies into construction engineering domain helps to enhance the level of lean construction [126].

5.2.2. Data-Driven Organizational Innovation. The innovation of technology has led to the change of managerial approaches in the AEC sector. Similarly, Big-Data-related technologies are gradually changing the organization model of CPM. Utilizing Big-Data-related technologies (e.g. cloud computing, VR, web-based, and agent-based) can facilitate the flow of information between internal microstructure and coordinate the work of each participant $[89,90]$. Generally, a construction project often involves a multidisciplinary team, which has a wide geographic distribution, while a variety of incompatible management information systems are employed [133]. Thus, it is significant to build a digital collaboration platform to share information effectively amongst distributed project stakeholders as Penã-Mora and Dwivedi [87] and Han et al. [88] proposed.

In addition, some preliminary studies explored the BIM and BSNS (business social networking services) federations based on cloud computing so as to enable data sharing not only by individuals or the management team but also by various organizations (enterprises) across the whole project lifecycle [85]. Similarly, aiming to support better decisionmaking for project stakeholders in the Big Data environment, SOA, as the software architecture, was established to foster the information integration and coordination within the construction supply chain management $[5,92]$. 


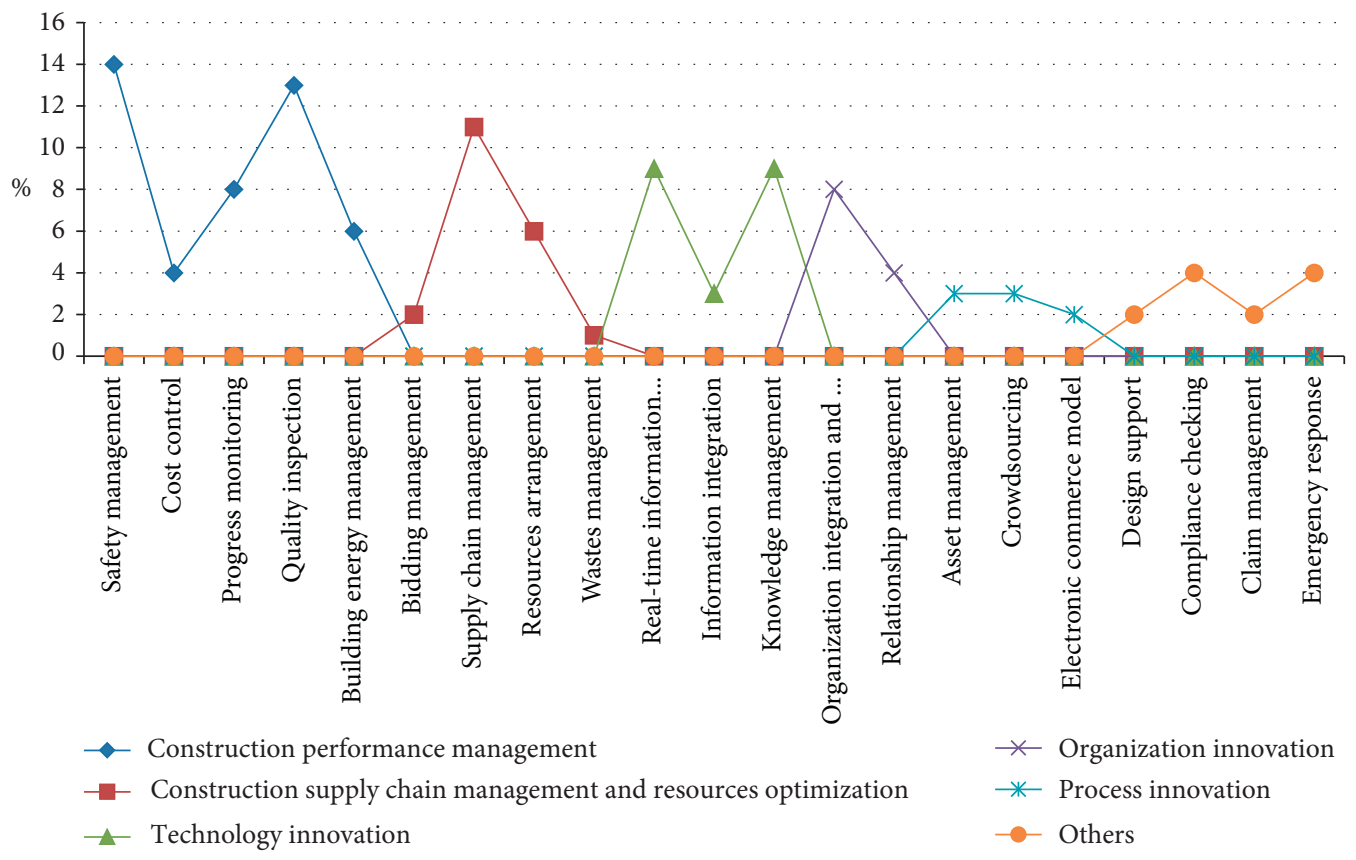

FIgURE 4: Distribution of research topics.



Figure 5: A comprehensive scenario of data-driven CPM. 
In short, with the application of Big-Data-related technologies, the construction project organization will be more flattened and flexible. The innovation of the organizational model can foster more effective communication, closer collaboration, and faster decision, all of which are critical to solve the dynamic and fragmented issues of the construction industry.

5.2.3. Data-Driven Process Innovation. As construction projects are gradually entering the Big Data era, asset information is becoming deliverable in the AEC sectors. As Morris [134] proposed, "reconstruction project management," digital technologies will change the project delivery model radically. For example, configuration management based on "Big Data analytics" delivers asset information across organizational boundaries. As a result, the asset information often contains design rationale, sources of components, maintenance schedule, and service life, etc. [93]. Indeed, for government invested infrastructure projects, the UK government had already required that the asset information must be delivered through BIM platform [93].

Meanwhile, the digital camera is reshaping the monitoring way for construction activities. Crowdsourcing is to monitor construction activities through the jobsite video streams gathering the intelligence of the crowd, which is one of the novel construction management models [96]. Crowdsourcing often relies on the intuitive web-based platform. It has been proven that crowdsourcing could minimize the time of workface judgment. The significant advantage of this novel management model is that it allows on-site professionals to concentrate on the key node tasks, ultimately improving the performance of CPM [96-98].

Similar to e-commerce business, the construction industry has its own integrated electronic commerce management model. For example, Zhang and Tiong [99] established a conceptual model about integrated e-commerce management model for the construction industry. Based on the context of Big Data, construction management innovations of the e-commerce model were explored in various aspects such as interaction between cost control and scheduling process at the project level, interaction between functional divisions and scheduling process at the enterprise level, and interaction between real-time weather information and scheduling process at the industry level.

There is an increasing level of complexity in construction projects. This is especially the case in megaprojects, which are considered as giant open complex systems. Big-Data-related technologies can assist the meta-synthesis of management processes, and finally achieve the emergence of metaintelligence.

\section{Future Research Agendas}

The diversification of research topics demonstrates that various emerging IT concepts have been introduced to explore effective ways to achieve the high quality of CPM under the Big Data scenario. Nevertheless, gaps still exist between the research status quo and the actual demands, which present research opportunities and challenges in the future.

6.1. Extension to Each Phase of Project Lifecycle. Most of the existing studies concentrated on the construction phase, while relatively few studies focused on planning/design phase even though this phase plays a key role in improving the performance of project management [131]. In current project practices, due to the diversity of systems and the limits of technique standards, such as BIM-related software, there is still poor interoperability between each other. This is despite the application of BIM being vigorously promoted in the construction industry. In addition to providing the visualization function to designers, the core role of BIM is to create a data integration platform for collaborative design of various majors and participants, in a bid to realize data (information) or knowledge sharing throughout the project lifecycle $[135,136]$. In particular, in the context of Big Data, the feasibility and necessity of planning and design process integrating with cloud computing should be paid more attention in advance [137]. Most of the time, however, BIM only contains the internal data of the construction industry, up until recently; this phenomenon has been changed due to the emergence of external data related to CPM. For example, some special interfaces enable the link between BIM and third-party databases or open datasets. Consequently, the historical engineering data, energy consumption data, weather variation data, or natural disasters data can be introduced. These will lead to the integration of internal data with external data in the construction industry through BIM. Therefore, Big Data analytics indeed is the key to design innovation and bring potential opportunities to optimize plan and update design.

Furthermore, some studies have attempted to apply BigData-related technologies in bid/procurement phase [72], such as KDD, VR, and ML. However, the degree of concern for this topic is still relatively low. For the sake of reducing the procurement cost or choosing the right contractor or supplier, the effective approach is to establish a knowledge management system, which contains materials' real-time price and qualifications of the bidder. In addition, with the emergence of IoTs, the conventional Internet is not able to cope with this new paradigm that links the physical world to the digital virtual world and to realize the real-time communication and information sharing between different participants in the construction supply chain [5]. But, mobile Internet gradually would play a crucial role in supply chain management in digital information time, especially for complex construction projects. Therefore, the expanding scale of construction market urgently requires the relevant technologies combined with Big Data analytics to improve the responsiveness.

For the operation/maintenance phase, existing studies mainly concentrated on the energy management and quality inspection of buildings. There are both challenges and opportunities to use various sensor networks in emergency response [138]. Some innovative technologies have been 
adopted in disaster response or rescue management, e.g., RFID, WLAN, AR, ZigBee-based, and so on [109, 139]. Nevertheless, it still needs to focus on how to improve the responsiveness and accuracy of emergency response in the complex internal space of buildings in the future. These include combining BIM with GIS data for disaster response in buildings; integrating GPS data with context-aware technology for analyzing the rescuer situation and supporting rescue decision-making. More efforts are required, eventually building a Big Data platform through the integration of these technologies. As a result, digital information is provided to assist post-disaster emergency responses and rescue operations. Moreover, it should be noted that there are few studies on the application of emerging IT on the recycling phase. How to minimize the construction waste presents a critical issue in the LCM of construction projects. Previous studies on waste management in construction projects mainly concerned environmental and techno-economic related factors, as well as impacts of resources policies [140-142]. Furthermore, existing waste analysis methods are subject to the restriction of static project attributes. However, design optimization can minimize the waste, which will be the future research trend. Especially, via discovery of implicit interaction between design stage and other stages, Big Data analytics would shift the wastes management approaches from passive governance to proactive analyses. Therefore, it warrants further investigation to investigate how the Big-Data-related technologies could be employed to consider dynamic project attributes, thereby minimizing the construction waste.

6.2. Strengthening Big Data Management in CPM. The application of emerging IT is increasingly popular in the construction industry, but it does not yet fully meet the desired data-driven CPM when faced with massive engineering data or information [6]. This situation is largely because most existing studies and practices concentrate on the data analytics and visualization aspects. By contrast, research on data management tasks (i.e., generation, acquisition, storage, processing, and security) for the engineering context is lacking. As the basis of data analytics, the ability of data management should be strengthened.

Data acquisition generally involves data collection and preprocessing [16], which are relatively simple in the manufacturing sector. Smart devices such as sensors and RFID tags can completely and accurately capture and transmit the Big Data related to the product lifecycle. Moreover, the less data noise, standardized data format, and integration of enterprise information systems facilitate processing data and sharing information [15]. By contrast, the data acquisition of the construction domain still faces numerous difficulties such as manual data entry, dynamic and static occlusions, and lack of uniform data format $[54,143]$. All these issues result in poor interoperability and compatibility. Therefore, future studies or practices should pay attention to these areas, for example, using text mining techniques to automate extracting information from documents and developing the common standard format for data exchange between heterogeneous modeling software.

According to the existing research analysis, a small amount of big Earth data (big geospatial data) are collected in the current process of construction. Big Earth data cover the fields of not only atmosphere, geography, geology, environment, and ecology but also information science, space science, cognitive science, and ones closely related to the humanities and social sciences [144]. They are expected to describe, analyze, model, and predict the dynamic processes of the Earth system as well as the interaction between humans and the planet by analyzing such massive data $[144,145]$. From smart cities' perspectives, the inclusion of BIM currently represents a relatively small part (a narrow building-level view) within the wider environmental context. External data such as atmosphere, geography, geology, environment, and ecology also need to be embedded into the BIM platform to support the management and decision-making of the whole lifecycle of the construction project. Moreover, in the face of the issues of massive volume and rapidly streaming big Earth data, cloud computing can provide critical support. It supports the processing of Big Data to address the $4 \mathrm{Vs}$ and obtain value for better decision support, research, and operations for various geospatial data [145]. Utilizing cloud computing to address big geospatial data challenges also applies to the construction industry.

The complexity of CPM practices and various digital information tools involved often lead to the nature of data mess and multisource heterogeneity. Data preprocessing is an important prerequisite to take advantage of acquired data [16]. Therefore, the data must be cleaned, integrated, and transformed through various tools such as Apache Hadoop, NoSQL, and MapReduce to extract meaningful information from Big Data [146]. After the extracting, transforming, and loading process, the data become applicable to data mining and various online analytics [16].

In addition, storage and processing of Big Data present significant challenges due to gradually complex CPM. Part of multisource heterogeneous data will be processed in real time by digital processing equipment. On the contrary, huge nonrealtime data will be stored as the raw data style for further data analysis [15]. With the increasing complexity of CPM, the total amount of relevant data has grown rapidly. This requires stronger computing ability possessed by the data processors and larger storage space configured by the data storage devices. Although the on-site automated tracking technique has been explored $[52,133]$, obstacles remain in data processing, such as lack of the fusing of data between various sources. In addition, data query is another issue in Big Data era [147-149]. Facing the huge amount of data, traditional databases will lose flexibility, especially when users attempt to ad hoc query in the information management systems. Therefore, to make it easier to access the stored data, online analytical processing and data warehouse should be further explored and exploited. In addition, there are great potentials and challenges to explore more friendly solutions such as natural language query solutions in the construction domain; for example, the exploration of ontologies from the text of construction contractual documents using natural language processing. 
6.3. Implementation of Comprehensive Data-Driven CPM. The traditional project management model is mainly based on reductionism. Thus, several innovative project management approaches (e.g. the meta-synthesis pattern of project management) have been put forward to improve project management performance $[128,129]$. Nowadays, the emergence of novel IT or data analytic methods in the construction domain is more conducive to the LCM metasynthesis of a project. Embracing and fusing technology innovations appropriately to create the next-generation IT platform for the AEC industry could usher the long-overdue industrial landscape changes.

Consequently, according to the status quo of the research and potential innovation trends, a comprehensive datadriven CPM scenario should be proposed as a response to the fast-growing practical demands on digital construction. The path to achieve this scenario within the context of Big Data is reflected in Figure 5. Data-driven technological innovation lays the foundation for the organizational and process innovation, and these innovations will further improve the management performance of construction projects. Specifically, this data-driven CPM scenario has the following features:

(i) Containing all stakeholders of the AEC industry, such as owners, architects, designers, contractors, project managers, and public officers

(ii) Achieving automated, model-based visual analytics for decision-making in all aspects of performance management, such as progress monitoring, construction quality and safety, and building and environmental sustainability

(iii) Allowing secure, ubiquitous information retrieval as well as visualized, intuitive remote operations for performing management tasks

(iv) Covering the whole project lifecycle including design, development, construction, operation, maintenance, repair, and retrofit of building physical infrastructure systems

(v) Forming an effective, transparent multi-stakeholder collaboration environment that minimizes conflicts among different parties and achieves maximum efficiency in planning coordination and contract execution

(vi) Integrating with the broader smart city framework and serving as a pillar to improve the urbanization quality of life from perspectives such as infrastructure availability, resiliency, and sustainability

Advanced BIM, IoT, computer vision, deep learning, cloud computing, AR, and blockchain technologies show potential in dealing with several important research challenges outlined in this proposal.

6.3.1. Visualization of the Digital Twin Data by Using BIM. Building-/Infrastructure-related information can be directly or indirectly integrated within available digital technologies in a BIM-enabled environment [150]. While the BIM paradigm was introduced to improve collaboration during design and construction, it quickly became involved in adjacent research areas across the built environment lifecycle at the building, infrastructure, and city levels. BIM now faces considerable challenges to automation and the inclusion of wider environmental contexts because it lacks semantic completeness in areas such as control systems, including sensor networks, social systems, and urban artifacts, beyond the scope of buildings [150]. Thus, a holistic, scalable semantic approach that factors in dynamic data at different levels is required. The combination of Big Data, IoT, and AI is heralded as a potential solution.

All studies related to smart cities or the AEC industry consider BIM as a part of the cyberphysical systems or digital twin (DT) as an important source of data [151]. DT integrates AI and data analytics to create dynamic digital models that can learn and update the status of the physical counterpart from multiple sources [151]. Therefore, the Big Databased LCM scenario is also accompanied by the concept of DT for restoring the complex construction environment, interactive design, simulation construction, and smart asset management.

6.3.2. Model Analytics Based on Full 3D Geometry. Deep learning, and especially supervised convolutional neural networks (CNN) are now state-of-the-art for object detection, image classification and retrieval, semantic segmentation, human pose estimation, and many other applications [152]. In the deep learning era, object classification, recognition, and retrieval in the visual analysis of $3 \mathrm{D}$ models could directly be based on full 3D geometry information, resulting in a more natural manner for interacting with the 3D world [153]. Therefore, with the continued fast development pace of computer processing power and deep learning algorithms, direct 3D object analytic methods could bring a new paradigm to the as-built and as-planned building model analytic topic.

6.3.3. Localization and Context Awareness for Visual Analytics. Another area deep learning technique may shed new light on is the common localization and context awareness challenge, which is the key to as-built visual data analytics and AR interactions. Promising works in this area demonstrate potential. For example, PoseNet [154] developed a deep-learning-based approach to metric localization by training a CNN to regress a camera pose. In the construction domain, state-of-the-art deep-learning-based localization and object recognition mechanisms, along with a priori geometric information from as-planned BIM and GIS, can be used to advance the automatic as-built 3D model building and visual analytic process.

6.3.4. Blockchain-Based Collaborative Infrastructure. Blockchain technology has already been described as the latest disruptive technology to many industries. Blockchain's decentralization, transparency, immutability, and smart contract features can solve many conflicts and coordination 
issues faced by these industries [155]. Typical projects in the construction industry could consist of hundreds of processes, participants, and products, thus making communication discrepancies, multiparty conflicts, change orders, and resource and schedule overrun a norm. In the construction site, blockchain can be used to improve the reliability and trustworthiness of the construction logbooks, works performed, and material quantities recorded. In the facility maintenance phase, blockchain's main potential is the secure storage of sensor data that are sensitive to privacy. In addition, multiparty intelligent contracts can be applied to guarantee payments for performance upon construction compliance [156]. Integrating with BIM, the process can leverage sensor-based monitoring or visual data analytics to confirm the completion of construction and engineering components, upon which the payment can be made automatically.

\section{Conclusions}

This study primarily aims to review and categorize developments in data, and forecast future research challenges and opportunities, in which the path to achieve a comprehensive data-driven CPM scenario based on technological, process, and organizational innovations within the context of Big Data is proposed. The review provides detailed insights to help understand the general trend of CPM phases, technology and application, and research topics. The major findings from this substantial review are as follows: (1) most researchers focus on the construction phase where various digital tools or methods used in other phases are far less than those in the construction phase. (2) The occurrence of BIM and ML technique are most common in CPM, which also reflects that most existing studies concentrate on the data analytics and visualization aspects for the engineering context. (3) More than half of the research focuses on two topics, namely, construction performance management and construction supply chain management and resource optimization.

Following the statistics of the existing studies, the particularized proposals in relation to each of the main topics within CPM is discussed. Furthermore, the corresponding future research agendas are proposed according to the advances and limitations of the current literature to bridge the gaps between theoretical research and practical demands: (1) extension to each phase in the whole project lifecycle, (2) strengthening Big Data management in CPM, and (3) implementation of comprehensive data-driven CPM. The path for achieving a data-driven CPM scenario within the context of Big Data is as follows: (1) visualization of DT data in CPM by using BIM, (2) model analytics based on full 3D geometry, (3) localization and context awareness for visual analytics, and (4) blockchain-based collaborative infrastructure.

This study reveals potential areas in which Big-Datarelated technologies can remarkably advance the state-ofthe-art in the AEC industry. The results can help AEC practitioners better understand how to encourage and manage the diffusion of emerging technologies in CPM. In addition, this study demonstrates that the integration of technology, process, and organization is needed to realize data-driven CPM. The result can help practitioners better understand how to achieve the performance goals of the construction project in the context of Big Data.

Not all aspects of big data or CPM fall within the scope of this review due to the design of the research methodology, leaving out several trails around the subject. In addition, topics such as programming models or mathematical algorithms will probably remain the main issue for years to come, which is not addressed here. A follow-up study is needed to improve the research by providing a more specialized review of frameworks and programming models/ algorithms for BDA to extend the information about the features, advantages, and limitations.

\section{Data Availability}

The data used to support the findings of this study are included within the article.

\section{Conflicts of Interest}

The authors declare that they have no conflicts of interest.

\section{Acknowledgments}

This work was supported by the National Natural Science Foundation of China (Grant no. 71771178) and China Scholarship Council (Grant no. 201806260091).

\section{References}

[1] J. Xu, "Engineering management: new advances and three open questions," International Journal of Management Science and Engineering Management, vol. 11, no. 2, pp. 71-77, 2016.

[2] B. Flyvbjerg, "Call for papers-special issue on classics in megaproject management," International Journal of Project Management, vol. 1, no. 33, pp. 1-2, 2015.

[3] A. H. Alavi and A. H. Gandomi, "Big data in civil engineering," Automation in Construction, vol. 79, 2017.

[4] Z. Zhou, J. Irizarry, and Q. Li, "Applying advanced technology to improve safety management in the construction industry: a literature review," Construction Management and Economics, vol. 31, no. 6, pp. 606-622, 2013.

[5] Q. Shi, X. Ding, J. Zuo, and G. Zillante, "Mobile internet based construction supply chain management: a critical review," Automation in Construction, vol. 72, pp. 143-154, 2016.

[6] M. Martinez-Rojas, N. Marin, and M. A. Vila, "The role of information technologies to address data handling in construction project management," Journal of Computing in Civil Engineering, vol. 30, no. 4, 2016.

[7] J.-R. Lin, Z.-Z. Hu, J.-P. Zhang, and F.-Q. Yu, "A naturallanguage-based approach to intelligent data retrieval and representation for cloud BIM," Computer-Aided Civil and Infrastructure Engineering, vol. 31, no. 1, pp. 18-33, 2016.

[8] M. Bilal, L. O. Oyedele, J. Qadir et al., "Big data in the construction industry: a review of present status, opportunities, and future trends," Advanced Engineering Informatics, vol. 30, no. 3, pp. 500-521, 2016. 
[9] A. Ø. Sørensen, N. Olsson, and A. D. Landmark, Big Data in Construction Management Research, Tampere University of Technology, Tampere, Finland, 2016.

[10] J. Manyika, M. Chui, B. Brown et al., Big Data: The Next Frontier for Innovation, Competition, and Productivity, Mckinsey \& Company Publishing, New York City, NY, USA, 2011.

[11] T. H. Davenport and J. Dyché, "Big data in big companies," International Institute for Analytics, vol. 3, 2013.

[12] G. Phillips-Wren and A. Hoskisson, "An analytical journey towards big data," Journal of Decision Systems, vol. 24, no. 1, pp. 87-102, 2015.

[13] R. Y. Zhong, S. T. Newman, G. Q. Huang, and S. Lan, "Big data for supply chain management in the service and manufacturing sectors: challenges, opportunities, and future perspectives," Computers \& Industrial Engineering, vol. 101, pp. 572-591, 2016.

[14] D. Laney, 3-D Data Management: Controlling Data Volume, Variety and Velocity, Vol. 949, META Group Inc, Stamford, CT, USA, 2001.

[15] Y. Zhang, S. Ren, Y. Liu, and S. Si, "A big data analytics architecture for cleaner manufacturing and maintenance processes of complex products," Journal of Cleaner Production, vol. 142, pp. 626-641, 2017.

[16] M. K. Saggi and S. Jain, "A survey towards an integration of big data analytics to big insights for value-creation," Information Processing \& Management, vol. 54, no. 5, pp. 758790, 2018.

[17] F. Kache and S. Seuring, "Challenges and opportunities of digital information at the intersection of big data analytics and supply chain management," International Journal of Operations \& Production Management, vol. 37, no. 1, pp. 10-36, 2017.

[18] K.-J. Wu, C.-J. Liao, M.-L. Tseng, M. K. Lim, J. Hu, and $\mathrm{K}$. Tan, "Toward sustainability: using big data to explore the decisive attributes of supply chain risks and uncertainties," Journal of Cleaner Production, vol. 142, pp. 663-676, 2017.

[19] H. Guo, H. Li, and M. Skitmore, "Life-cycle management of construction projects based on virtual prototyping technology," Journal of Management in Engineering, vol. 26, no. 1, pp. 41-47, 2009.

[20] J. Teresko, “The PLM revolution," Auto report: information technology, Industry Week, Cleveland, OH, USA, 2004.

[21] B. Schilli and F. Dai, "Collaborative life cycle management between suppliers and OEM," Computers in Industry, vol. 57, no. 8-9, pp. 725-731, 2006.

[22] B. A. Omran and Q. Chen, "Trend on the implementation of analytical techniques for big data in construction research (2000-2014)," in Proceedings of the Construction Research Congress, pp. 990-999, San Juan, Puerto Rico, May 2016.

[23] Y. Rezgui and A. Zarli, "Paving the way to the vision of digital construction: a strategic roadmap," Journal of Construction Engineering and Management, vol. 132, no. 7, pp. 767-776, 2006.

[24] Y. Lu, Y. Li, M. Skibniewski, Z. Wu, R. Wang, and Y. Le, "Information and communication technology applications in architecture, engineering, and construction organizations: a 15-year review," Journal of Management in Engineering, vol. 31, no. 1, 2015.

[25] C. Fan, F. Xiao, Z. Li, and J. Wang, "Unsupervised data analytics in mining big building operational data for energy efficiency enhancement: a review," Energy and Buildings, vol. 159, pp. 296-308, 2018.
[26] H. Yan, N. Yang, Y. Peng, and Y. Ren, "Data mining in the construction industry: present status, opportunities, and future trends," Automation in Construction, vol. 119, Article ID 103331, 2020.

[27] A. Darko, A. P. C. Chan, M. A. Adabre, D. J. Edwards, M. R. Hosseini, and E. E. Ameyaw, "Artificial intelligence in the AEC industry: scientometric analysis and visualization of research activities," Automation in Construction, vol. 112, Article ID 103081, 2020.

[28] Z. Xianbo, Z. Jian, W. Guangdong, and H. Can, "A bibliometric review of green building research 2000-2016," Architectural Science Review, vol. 62, no. 1, pp. 74-88, 2018.

[29] E. Archambault, D. Campbell, Y. Gingras, and V. Lariviere, "Comparing bibliometric statistics obtained from the web of science and Scopus," Journal of the American Society for Information Science \& Technology, vol. 60, no. 7, pp. 13201326, 2010.

[30] M. Abdelsayed and R. Navon, "An information sharing, internet-based, system for project control," Civil Engineering and Environmental Systems, vol. 16, no. 3, pp. 211-233, 1999.

[31] Z. Aziz, C. J. Anumba, D. Ruikar, P. Carrillo, and D. Bouchlaghem, "Intelligent wireless web services for construction-a review of the enabling technologies," Automation in Construction, vol. 15, no. 2, pp. 113-123, 2006.

[32] Y. Huang, Q. Shi, F. Pena-Mora, Y. Lu, and C. Shen, "Exploring the impact of information and communication technology on team social capital and construction project performance," Journal of Management in Engineering, vol. 36, no. 5, Article ID 04020056, 2020.

[33] T. M. Froese, "The impact of emerging information technology on project management for construction," Automation in Construction, vol. 19, no. 5, pp. 531-538, 2010.

[34] V. K. Bansal, "Application of geographic information systems in construction safety planning," International Journal of Project Management, vol. 29, no. 1, pp. 66-77, 2011.

[35] C.-W. Liao and Y.-H. Perng, "Data mining for occupational injuries in the Taiwan construction industry," Safety Science, vol. 46, no. 7, pp. 1091-1102, 2008.

[36] C.-W. Cheng, C.-C. Lin, and S.-S. Leu, "Use of association rules to explore cause-effect relationships in occupational accidents in the Taiwan construction industry," Safety Science, vol. 48, no. 4, pp. 436-444, 2010.

[37] H. Yang, D. A. S. Chew, W. Wu, Z. Zhou, and Q. Li, "Design and implementation of an identification system in construction site safety for proactive accident prevention," Accident Analysis \& Prevention, vol. 48, no. 5, pp. 193-203, 2012.

[38] A. Kelm, L. Laubat, A. Meins-Becker et al., "Mobile passive radio frequency identification (RFID) portal for automated and rapid control of personal protective equipment (PPE) on construction sites," Automation in Construction, vol. 36, no. 36, pp. 38-52, 2013.

[39] N. Nenonen, "Analysing factors related to slipping, stumbling, and falling accidents at work: application of data mining methods to Finnish occupational accidents and diseases statistics database," Applied Ergonomics, vol. 44, no. 2, pp. 215-224, 2013.

[40] M. Amiri, A. Ardeshir, M. H. Fazel Zarandi, and E. Soltanaghaei, "Pattern extraction for high-risk accidents in the construction industry: a data-mining approach," International Journal of Injury Control and Safety Promotion, vol. 23, no. 3, pp. 264-276, 2016.

[41] L. Y. Ding, B. T. Zhong, S. Wu, and H. B. Luo, "Construction risk knowledge management in BIM using ontology and 
semantic web technology," Safety Science, vol. 87, pp. 202213, 2016.

[42] H. Li, X. Yang, F. Wang, T. Rose, G. Chan, and S. Dong, "Stochastic state sequence model to predict construction site safety states through real-time location systems," Safety Science, vol. 84, pp. 78-87, 2016.

[43] L. Ding, W. Fang, H. Luo, P. E. D. Love, B. Zhong, and X. Ouyang, "A deep hybrid learning model to detect unsafe behavior: integrating convolution neural networks and long short-term memory," Automation in Construction, vol. 86, pp. 118-124, 2018.

[44] W. Fang, L. Ding, H. Luo, and P. E. D. Love, "Falls from heights: a computer vision-based approach for safety harness detection," Automation in Construction, vol. 91, pp. 53-61, 2018.

[45] W. Fang, L. Ding, B. Zhong, P. E. D. Love, and H. Luo, "Automated detection of workers and heavy equipment on construction sites: a convolutional neural network approach," Advanced Engineering Informatics, vol. 37, 2018.

[46] I. W. Fu, C. B. Markegard, B. K. Chu, and H. D. Nguyen, "The effect of current public procurement law on duration and cost of construction projects in Turkey," Journal of Civil Engineering \& Management, vol. 19, no. 1, pp. 121-135, 2013.

[47] S.-K. Lee, K.-R. Kim, and J.-H. Yu, "BIM and ontology-based approach for building cost estimation," Automation in Construction, vol. 41, pp. 96-105, 2014.

[48] M. Niknam and S. Karshenas, "Integrating distributed sources of information for construction cost estimating using semantic web and semantic web service technologies," $A u$ tomation in Construction, vol. 57, pp. 222-238, 2015.

[49] S. Chin, S. Yoon, C. Choi, and C. Cho, "RFID+4D CAD for progress management of structural steel works in high-rise buildings," Journal of Computing in Civil Engineering, vol. 22, no. 2, pp. 74-89, 2008.

[50] M. Golparvar-Fard, J. Bohn, J. Teizer, S. Savarese, and F. Peña-Mora, "Evaluation of image-based modeling and laser scanning accuracy for emerging automated performance monitoring techniques," Automation in Construction, vol. 20, no. 8, pp. 1143-1155, 2011.

[51] M. Golparvar-Fard, F. Peña-Mora, and S. Savarese, "Automated progress monitoring using unordered daily construction photographs and IFC-based building information models," Journal of Computing in Civil Engineering, vol. 29, no. 1, Article ID 04014025, 2012.

[52] A. Shahi, M. Safa, C. T. Haas, and J. S. West, "Data fusion process management for automated construction progress estimation," Journal of Computing in Civil Engineering, vol. 29, no. 6, Article ID 04014098, 2014.

[53] A. Hammad, S. AbouRizk, and Y. Mohamed, "Application of KDD techniques to extract useful knowledge from labor resources data in industrial construction projects," Journal of Management in Engineering, vol. 30, no. 6, 2014.

[54] K. K. Han and M. Golparvar-Fard, "Appearance-based material classification for monitoring of operation-level construction progress using 4D BIM and site photologs," Automation in Construction, vol. 53, pp. 44-57, 2015.

[55] M. M. Ghazal and A. Hammad, "Application of knowledge discovery in database (KDD) techniques in cost overrun of construction projects,", 2020.

[56] Q. Chen, Y. W. Chan, and K. Worden, "Structural fault diagnosis and isolation using neural networks based on response-only data," Computers \& Structures, vol. 81, no. 2223, pp. 2165-2172, 2003.
[57] X. Fang, H. Luo, and J. Tang, "Structural damage detection using neural network with learning rate improvement," Computers \& Structures, vol. 83, no. 25-26, pp. 2150-2161, 2005.

[58] J. Yagi, E. Arai, and T. Arai, "Parts and packets unification radio frequency identification (RFID) application for construction," Automation in Construction, vol. 14, no. 4, pp. 477-490, 2005.

[59] E. Ergen, B. Akinci, and R. Sacks, "Life-cycle data management of engineered-to-order components using radio frequency identification," Advanced Engineering Informatics, vol. 21, no. 4, pp. 356-366, 2007.

[60] Y. S. Kim, S. W. Oh, Y. K. Cho, and J. W. Seo, “A PDA and wireless web-integrated system for quality inspection and defect management of apartment housing projects," Automation in Construction, vol. 17, no. 2, pp. 163-179, 2008.

[61] M. M. Torok, M. Golparvar-Fard, and K. B. Kochersberger, "Image-based automated 3D crack detection for post-disaster building assessment," Journal of Computing in Civil Engineering, vol. 28, no. 5, 2013.

[62] Y. Cheng, W.-d. Yu, and Q. Li, "GA-based multi-level association rule mining approach for defect analysis in the construction industry," Automation in Construction, vol. 51, pp. 78-91, 2015.

[63] F. N. Catbas and M. Malekzadeh, "A machine learning-based algorithm for processing massive data collected from the mechanical components of movable bridges," Automation in Construction, vol. 72, pp. 269-278, 2016.

[64] E. B. Anil, B. Akinci, J. H. Garrett, and O. Kurc, "Information requirements for earthquake damage assessment of structural walls," Advanced Engineering Informatics, vol. 30, no. 1, pp. 54-64, 2016.

[65] H. Zhu, X. Wang, X. Chen, and L. Zhang, "Similarity search and performance prediction of shield tunnels in operation through time series data mining," Automation in Construction, vol. 114, Article ID 103178, 2020.

[66] S. Mustapha, A. Kassir, K. Hassoun, Z. Dawy, and H. AbiRached, "Estimation of crowd flow and load on pedestrian bridges using machine learning with sensor fusion," Automation in Construction, vol. 112, Article ID 103092, 2020.

[67] C. Miller, Z. Nagy, and A. Schlueter, "Automated daily pattern filtering of measured building performance data," Automation in Construction, vol. 49, no. A, pp. 1-17, 2015.

[68] F. Cabrera, R. Shin, D. Concha et al., "Temporal knowledge discovery in big BAS data for building energy management," Energy \& Buildings, vol. 109, no. 4, pp. 75-89, 2015.

[69] A. H. Oti, E. Kurul, F. Cheung, and J. H. M. Tah, "A framework for the utilization of building management system data in building information models for building design and operation," Automation in Construction, vol. 72, pp. 195-210, 2016.

[70] T. Gerrish, K. Ruikar, M. Cook, M. Johnson, M. Phillip, and C. Lowry, "BIM application to building energy performance visualisation and management: challenges and potential," Energy \& Buildings, vol. 144, pp. 218-228, 2017.

[71] T. Cheng, Y. Wang, and Y. Sun, "Development and application of tender evaluation decision-making and risk early warning system for water projects based on KDD," Advances in Engineering Software, vol. 48, pp. 58-69, 2012.

[72] E. O. Ibem and S. Laryea, "Survey of digital technologies in procurement of construction projects," Automation in Construction, vol. 46, no. 46, pp. 11-21, 2014.

[73] M. J. Skibniewski and W.-S. Jang, "Simulation of accuracy performance for wireless sensor-based construction asset 
tracking," Computer-Aided Civil and Infrastructure Engineering, vol. 24, no. 5, pp. 335-345, 2010.

[74] W. Lu, G. Q. Huang, and H. Li, "Scenarios for applying RFID technology in construction project management," Automation in Construction, vol. 20, no. 2, pp. 101-106, 2011.

[75] Z. Ren, C. J. Anumba, and J. Tah, "RFID-facilitated construction materials management (RFID-CMM) - a case study of water-supply project," Advanced Engineering Informatics, vol. 25, no. 2, pp. 198-207, 2011.

[76] V. Hinkka and J. Tätilä, "RFID tracking implementation model for the technical trade and construction supply chains," Automation in Construction, vol. 35, pp. 405-414, 2013.

[77] R. Akhavian and A. H. Behzadan, "Knowledge-based simulation modeling of construction fleet operations using multimodal-process data mining," Journal of Construction Engineering and Management, vol. 139, no. 11, 2013.

[78] H. Moon, H.-k. Lee, Y.-s. Lee, and J.-J. Kim, "Earth information system (EIS) for the reuse of resources between construction sites," Journal of Asian Architecture and Building Engineering, vol. 6, no. 2, pp. 267-274, 2007.

[79] M. Bilal, L. O. Oyedele, O. O. Akinade et al., "Big data architecture for construction waste analytics (CWA): a conceptual framework," Journal of Building Engineering, vol. 6, pp. 144-156, 2016.

[80] R. R. Lipman, "Mobile 3D visualization for steel structures," Automation in Construction, vol. 13, no. 1, pp. 119-125, 2004.

[81] Y. Nielsen and O. Koseoglu, "Wireless networking in tunnelling projects," Tunnelling and Underground Space Technology, vol. 22, no. 3, pp. 252-261, 2007.

[82] S.-w. Leung, S. Mak, and B. L. P. Lee, "Using a real-time integrated communication system to monitor the progress and quality of construction works," Automation in Construction, vol. 17, no. 6, pp. 749-757, 2008.

[83] U.-K. Lee, K.-I. Kang, G.-H. Kim, and H.-H. Cho, "Improving tower crane productivity using wireless technology," Computer-Aided Civil and Infrastructure Engineering, vol. 21, no. 8, pp. 594-604, 2010.

[84] X. Wang, P. E. D. Love, M. J. Kim, C.-S. Park, C.-P. Sing, and L. Hou, "A conceptual framework for integrating building information modeling with augmented reality," Automation in Construction, vol. 34, no. 13, pp. 37-44, 2013.

[85] Y. Jiao, Y. Wang, S. Zhang, Y. Li, B. Yang, and L. Yuan, “A cloud approach to unified lifecycle data management in architecture, engineering, construction and facilities management: integrating BIMs and SNS," Advanced Engineering Informatics, vol. 27, no. 2, pp. 173-188, 2013.

[86] E. Elwakil and T. Zayed, "Construction productivity fuzzy knowledge base management system," Canadian Journal of Civil Engineering, vol. 45, no. 5, pp. 329-338, 2017.

[87] F. Penã-Mora and G. H. Dwivedi, "Multiple device collaborative and real time analysis system for project management in civil engineering," Journal of Computing in Civil Engineering, vol. 16, no. 1, pp. 23-38, 2001.

[88] S. H. Han, K. H. Chin, and M. J. Chae, "Evaluation of CITIS as a collaborative virtual organization for construction project management," Automation in Construction, vol. 16, no. 2, pp. 199-211, 2007.

[89] X. Xue, Q. Shen, H. Fan, H. Li, and S. Fan, "IT supported collaborative work in A/E/C projects: a ten-year review," Automation in Construction, vol. 21, no. 1, pp. 1-9, 2012.

[90] J. Du, M. El-Gafy, and P. Lama, "A cloud-based shareable library of cooperative behaviors for agent based modeling in construction," Automation in Construction, vol. 62, pp. 89$100,2016$.

[91] X. Xue, X. Li, Q. Shen, and Y. Wang, "An agent-based framework for supply chain coordination in construction," Automation in Construction, vol. 14, no. 3, pp. 413-430, 2005.

[92] T.-H. Shin, S. Chin, S.-W. Yoon, and S.-W. Kwon, "A service-oriented integrated information framework for RFID/ WSN-based intelligent construction supply chain management," Automation in Construction, vol. 20, no. 6, pp. 706-715, 2011.

[93] J. Whyte, A. Stasis, and C. Lindkvist, "Managing change in the delivery of complex projects: configuration management, asset information and big data," International Journal of Project Management, vol. 34, no. 2, pp. 339-351, 2016.

[94] H. B. Cavka, S. Staub-French, and E. A. Poirier, "Developing owner information requirements for BIM-enabled project delivery and asset management," Automation in Construction, vol. 83, pp. 169-183, 2017.

[95] J. P. Carneiro, M. P. Varnosfaderani, V. Balali, and A. Heydarian, "Comprehensible and interactive visualizations of spatial building data in augmented reality," in Proceedings of the Computing in Civil Engineering, pp. 79-86, Atlanta, Georgia, June 2019.

[96] K. Liu and M. Golparvar-Fard, "Crowdsourcing construction activity analysis from jobsite video streams," Journal of Construction Engineering \& Management, vol. 141, no. 11, Article ID 04015035, 2014.

[97] J. Yang, M.-W. Park, P. A. Vela, and M. Golparvar-Fard, "Construction performance monitoring via still images, time-lapse photos, and video streams: now, tomorrow, and the future," Advanced Engineering Informatics, vol. 29, no. 2, pp. 211-224, 2015.

[98] K. K. Han and M. Golparvar-Fard, "Potential of big visual data and building information modeling for construction performance analytics: an exploratory study," Automation in Construction, vol. 73, pp. 184-198, 2016.

[99] N. Zhang and R. Tiong, "Integrated electronic commerce model for the construction industry," Journal of Construction Engineering and Management, vol. 129, no. 5, pp. 578-585, 2003.

[100] Y. Wang, J. Yang, and Q. Shen, "The application of electronic commerce and information integration in the construction industry," International Journal of Project Management, vol. 25, no. 2, pp. 158-163, 2007.

[101] C. J. Romanowski, R. Nagi, and M. Sudit, "Data mining in an engineering design environment: OR applications from graph matching," Computers \& Operations Research, vol. 33, no. 11, pp. 3150-3160, 2006.

[102] F. Tang, T. Ma, J. Zhang, Y. Guan, and L. Chen, "Integrating three-dimensional road design and pavement structure analysis based on BIM," Automation in Construction, vol. 113, Article ID 103152, 2020.

[103] J. Zhang and N. M. El-Gohary, "Semantic NLP-based information extraction from construction regulatory documents for automated compliance checking," Journal of Computing in Civil Engineering, vol. 30, no. 2, 2016.

[104] S. Li, H. B. Cai, and V. R. Kamat, "Integrating natural language processing and spatial reasoning for utility compliance checking," Journal of Construction Engineering and Management, vol. 142, no. 12, 2016.

[105] D. M. Salama and N. M. El-Gohary, "Semantic text classification for supporting automated compliance checking in construction," Journal of Computing in Civil Engineering, vol. 30, no. 1, 2016. 
[106] D. Arditi and T. Pulket, "Predicting the outcome of construction litigation using boosted decision trees," Journal of Computing in Civil Engineering, vol. 19, no. 4, pp. 387-393, 2005.

[107] J.-H. Chen and S. C. Hsu, "Hybrid ANN-CBR model for disputed change orders in construction projects," Automation in Construction, vol. 17, no. 1, pp. 56-64, 2007.

[108] F. Peña-Mora, A. Y. Chen, Z. Aziz et al., "Mobile Ad Hoc network-enabled collaboration framework supporting civil engineering emergency response operations," Journal of Computing in Civil Engineering, vol. 24, no. 3, pp. 302-312, 2010.

[109] N. Li, B. Becerik-Gerber, L. Soibelman, and B. Krishnamachari, "Comparative assessment of an indoor localization framework for building emergency response," Automation in Construction, vol. 57, pp. 42-54, 2015.

[110] Z. Aziz, "Supporting site-based processes using contextaware virtual prototyping," Journal of Architectural Engineering, vol. 18, no. 2, pp. 79-83, 2012.

[111] X. Zhao, R. Lovreglio, and D. Nilsson, "Modelling and interpreting pre-evacuation decision-making using machine learning," Automation in Construction, vol. 113, Article ID 103140, 2020.

[112] M. D’Orazio, S. Longhi, P. Olivetti, and G. Bernardini, "Design and experimental evaluation of an interactive system for pre-movement time reduction in case of fire," Automation in Construction, vol. 52, pp. 16-28, 2015.

[113] I. Motawa and A. Almarshad, "A knowledge-based BIM system for building maintenance," Automation in Construction, vol. 29, pp. 173-182, 2013.

[114] B. Succar and E. Poirier, "Lifecycle information transformation and exchange for delivering and managing digital and physical assets," Automation in Construction, vol. 112, Article ID 103090, 2020.

[115] A. Salem and O. Moselhi, "AI-based cloud computing application for smart earthmoving operations," Canadian Journal of Civil Engineering, vol. 48, no. 3, pp. 312-327, 2020.

[116] J. Fu, E. Jenelius, and H. N. Koutsopoulos, "Identification of workstations in earthwork operations from vehicle GPS data," Automation in Construction, vol. 83, pp. 237-246, 2017.

[117] S. E. Poku and D. Arditi, "Construction scheduling and progress control using geographical information systems," Journal of Computing in Civil Engineering, vol. 20, no. 5, pp. 351-360, 2006.

[118] H. Kim, L. Soibelman, and F. Grobler, "Factor selection for delay analysis using knowledge discovery in databases," Automation in Construction, vol. 17, no. 5, pp. 550-560, 2008.

[119] M. Al Qady and A. Kandil, "Concept relation extraction from construction documents using natural language processing," Journal of Construction Engineering and Management, vol. 136, no. 3, pp. 294-302, 2010.

[120] H.-B. Liu and Y.-B. Jiao, "Application of genetic algorithmsupport vector machine (GA-SVM) for damage identification of bridge," International Journal of Computational Intelligence and Applications, vol. 10, no. 4, pp. 383-397, 2011.

[121] T. Mahfouz, J. Jones, and A. Kandil, "A machine learning approach 101 for automated document classification: A comparison between svm 102 and lsa performances," International Journal of Engineering Research \& Innovation, pp. 53-62, 2010.

[122] D. Zhong, H. Lv, J. Han, and Q. Wei, “A practical application combining wireless sensor networks and internet of things: safety management system for tower crane groups," Sensors, vol. 14, no. 8, pp. 13794-13814, 2014.

[123] X. Luo, F. Leite, M. Asce, and W. J. O. 'Brien, "Locationaware sensor data error impact on autonomous crane safety monitoring," Journal of Computing in Civil Engineering, vol. 29, no. 4, 2014.

[124] R. Akhavian and A. H. Behzadan, "Evaluation of queuing systems for knowledge-based simulation of construction processes," Automation in Construction, vol. 47, pp. 37-49, 2014.

[125] E. J. Jaselskis and T. El-Misalami, "Implementing radio frequency identification in the construction process," Journal of Construction Engineering and Management, vol. 129, no. 6, pp. 680-688, 2003.

[126] B. Dave, S. Kubler, K. Främling, and L. Koskela, “Opportunities for enhanced lean construction management using internet of things standards," Automation in Construction, vol. 61, pp. 86-97, 2016.

[127] D. D. Gransberg and M. A. Ellicott, "Life cycle project management," AACE International Transactions, American Association of Cost Engineers, 1997.

[128] Q. He, W. Jiang, Y. Li, and Y. Le, "The study on paradigm shift of project management based on complexity scienceproject management innovations," in Proceedings of the Shanghai 2010 EXPO Construction Program, Industrial Engineering and Engineering Management, pp. 603-607, IEEE, Shanghai, China, 2010.

[129] M. Mihić and Z. Dodevska, "Innovation project management between the Newtonian paradigm and the complexity paradigm," Serbian Project Management Journal, vol. 5, no. 1, pp. 10-17, 2015.

[130] W. Zhou, J. Whyte, and R. Sacks, "Construction safety and digital design: a review," Automation in Construction, vol. 22, pp. 102-111, 2012.

[131] R. Szymberski, "Construction project safety planning," Tappi Journal (USA), 1997.

[132] P. Tang, D. Huber, B. Akinci, R. Lipman, and A. Lytle, "Automatic reconstruction of as-built building information models from laser-scanned point clouds: a review of related techniques," Automation in Construction, vol. 19, no. 7, pp. 829-843, 2010.

[133] W. Shen, Q. Hao, H. Mak et al., "Systems integration and collaboration in architecture, engineering, construction, and facilities management: a review," Advanced Engineering Informatics, vol. 24, no. 2, pp. 196-207, 2010.

[134] P. W. G. Morris, "Procurement and the project's commercial management," in Reconstructing Project Management, Wiley, Chichester, UK, 2013.

[135] K. Barlish and K. Sullivan, "How to measure the benefits of BIM-a case study approach," Automation in Construction, vol. 24, no. 2, pp. 149-159, 2012.

[136] S. Azhar, "Building information modeling (BIM): trends, benefits, risks, and challenges for the AEC industry," Leadership and Management in Engineering, vol. 11, no. 3, pp. 241-252, 2011.

[137] E. Curry, J. O’Donnell, E. Corry, S. Hasan, M. Keane, and S. O'Riain, "Linking building data in the cloud: integrating cross-domain building data using linked data," Advanced Engineering Informatics, vol. 27, no. 2, pp. 206-219, 2013.

[138] K. Lorincz, D. J. Malan, T. R. F. Fulford-Jones et al., "Sensor networks for emergency response: challenges and opportunities," IEEE Pervasive Computing, vol. 3, no. 4, pp. 16-23, 2005. 
[139] U. Isikdag, J. Underwood, G. Aouad, and N. Trodd, "Investigating the role of building information models as a part of an integrated data layer: a fire response management case," Architectural Engineering and Design Management, vol. 3, no. 2, pp. 124-142, 2007.

[140] B. A. G. Bossink and H. J. H. Brouwers, "Construction waste: quantification and source evaluation," Journal of Construction Engineering \& Management, vol. 122, no. 1, pp. 55-60, 2017.

[141] W. Lu, X. Chen, Y. Peng, and L. Shen, "Benchmarking construction waste management performance using big data," Resources, Conservation and Recycling, vol. 105, pp. 49-58, 2015.

[142] M. Osmani, J. Glass, and A. Price, "Architect and contractor attitudes to waste minimisation," Proceedings of the Institution of Civil Engineers - Waste and Resource Management, vol. 159, no. 2, pp. 65-72, 2006.

[143] J. Seo, S. Han, S. Lee, and H. Kim, "Computer vision techniques for construction safety and health monitoring," Advanced Engineering Informatics, vol. 29, no. 2, pp. 239251, 2015.

[144] H. Guo, Z. Liu, H. Jiang, C. Wang, J. Liu, and D. Liang, "Big earth data: a new challenge and opportunity for digital earth's development," International Journal of Digital Earth, vol. 10, no. 1, pp. 1-12, 2017.

[145] C. Yang, M. Yu, F. Hu, Y. Jiang, and Y. Li, "Utilizing cloud computing to address big geospatial data challenges," Computers Environment \& Urban Systems, vol. 61, pp. 120-128, 2016.

[146] H. Hu, Y. Wen, C. Tat-Seng, and X. Li, "Toward scalable systems for big data analytics: a technology tutorial," IEEE Access, vol. 2, pp. 652-687, 2014.

[147] J. T. Cadenas, N. Marín, and M. A. Vila, "Context-aware fuzzy databases," Applied Soft Computing, vol. 25, no. C, pp. 215-233, 2014.

[148] H. Bae, M. Golparvar-Fard, and J. White, "High-precision vision-based mobile augmented reality system for contextaware architectural, engineering, construction and facility management (AEC/FM) applications," Visualization in Engineering, vol. 1, no. 1, p. 3, 2013.

[149] X. Liu, B. Akinci, M. Bergés, and J. H. Garrett, "Domainspecific querying formalisms for retrieving information about HVAC systems," Journal of Computing in Civil Engineering, vol. 28, no. 1, pp. 40-49, 2014.

[150] O. Per-Ola, A. Josefine, H. Martin, and H. Lars, "Automation of building permission by integration of BIM and geospatial data," International Journal of Geo-Information, vol. 7, no. 8, p. 307, 2018.

[151] Q. Lu, X. Xie, J. Heaton, A. K. Parlikad, and J. Schooling, "From BIM towards digital twin: strategy and future development for smart asset management," in Proceedings of the Service Oriented, Holonic and Multi-agent Manufacturing Systems for Industry of the Future, Studies in Computational Intelligence, Paris, France, October 2020.

[152] X. Wang, "Deep learning in object recognition, detection, and segmentation," Foundations and Trends in Signal Processing, vol. 8, no. 4, pp. 217-382, 2016.

[153] A. Ioannidou, E. Chatzilari, S. Nikolopoulos, and I. Kompatsiaris, "Deep learning advances in computer vision with 3D data: a survey," ACM Computing Surveys, vol. 50, no. 2, pp. 20-21, 2017.

[154] A. Kendall, M. Grimes, and R. Cipolla, "PoseNet: a convolutional network for real-time 6-dof camera relocalization," in Proceedings of the 2015 IEEE International
Conference on Computer Vision (ICCV), Las Condes, Chile, December 2015.

[155] C. Shen and F. Pena-Mora, "Blockchain for cities-a systematic literature review," IEEE Access, vol. 6, pp. 7678776819, 2018.

[156] A. Heiskanen, "The technology of trust: how the internet of things and blockchain could usher in a new era of construction productivity," Construction Research and Innovation, vol. 8, no. 2, pp. 66-70, 2017. 